\title{
(อ) OPEN ACCESS \\ Evolution of therapies for the corneal endothelium: past, present and future approaches
}

\author{
Hon Shing Ong (D) , 1,2,3 Marcus Ang (D) , 1,3 Jodhbir S Mehta1,2,3,4
}

${ }^{1}$ Corneal and External Diseases Department, Singapore National Eye Centre, Singapore

Singapore

${ }^{2}$ Tissue Engineering and Cell Therapy Group, Singapore Eye Research Institute, Singapore, Singapore

${ }^{3}$ Department of Ophthalmology and Visual Science, DukeNational University of Singapore (NUS) Graduate Medical School Singapore, Singapore ${ }^{4}$ School of Material Science \& Engineering and School of Mechanical and Aerospace Engineering, Nanyang Technological University, Singapore, Singapore

Correspondence to Jodhbir S Mehta, Singapore National Eye Centre, 11 Third Hospital Avenue, Singapore, Singapore; jodmehta@gmail. com and Hon Shing Ong; honshing@gmail.com

Received 23 February 2020 Revised 16 May 2020 Published Online First 22 July 2020
Check for updates

(C) Author(s) (or their employer(s)) 2021. Re-use permitted under CC BY-NC. No commercial re-use. See rights and permissions. Published by BMJ.

To cite: Ong HS, Ang M, Mehta JS. Br J Ophthalmol 2021:105:454-467.
ABSTRACT Corneal endothelial diseases are leading indications for corneal transplantations. With significant advancement in medical science and surgical techniques, corneal transplant surgeries are now increasingly effective at restoring vision in patients with corneal diseases. In the last 15 years, the introduction of endothelial keratoplasty (EK) procedures, where diseased corneal endothelium (CE) are selectively replaced, has significantly transformed the field of corneal transplantation. Compared to traditional penetrating keratoplasty, EK procedures, namely Descemet's stripping automated endothelial keratoplasty (DSAEK) and Descemet membrane endothelial keratoplasty (DMEK), offer faster visual recovery, lower immunological rejection rates, and improved graft survival. Although these modern techniques can achieve high success, there are fundamental impediments to conventional transplantations. A lack of suitable donor corneas worldwide restricts the number of transplants that can be performed. Other barriers include the need for specialized expertise, high cost, and risks of graft rejection or failure. Research is underway to develop alternative treatments for corneal endothelial diseases, which are less dependent on the availability of allogeneic tissues - regenerative medicine and cell-based therapies. In this review, an overview of past and present transplantation procedures used to treat corneal endothelial diseases are described. Potential novel therapies that may be translated into clinical practice will also be presented.

\section{INTRODUCTION}

A healthy corneal endothelium (CE) is essential in supporting an ideal level of corneal hydration (approximately 78\% aqueous). This maintains an ideal spacing of stromal collagen lamellae, which is important in keeping the cornea transparent. ${ }^{12}$ In the early neonatal period, the human corneal endothelial cell density (ECD) is estimated to be around 6000 cells $/ \mathrm{mm}^{2} .^{3}{ }^{4}$ Subsequently, ECD falls to $3000-3500$ cells $/ \mathrm{mm}^{2}$ by early childhood as a result of normal growth in corneal size and concurrent cellular attrition. ${ }^{4}$ Thereafter, there is a continuing loss in ECD of approximately $0.6 \%$ each year, so that the average ECD at 85 years of age is approximately 2300 cells $/ \mathrm{mm}^{2}{ }^{4} 67$ This physiological decline in ECD throughout life does not normally affect the normal structure and function of the cornea.

An accelerated corneal endothelial cells (CECs) attrition above the natural decline in ECD can be caused by specific pathological conditions including Fuchs endothelial corneal dystrophy (FECD) or various insults to the CE (eg, intraocular surgeries, anterior segment laser treatments, intraocular inflammation, infections, direct physical trauma). ${ }^{4} 89$ A loss in ECD below a pathological level (typically $<500-600$ cells $/ \mathrm{mm}^{2}$ ) can compromise the capacity of the CE to maintain corneal hydration. ${ }^{8} 1011$ When this occurs, the cornea loses its transparency from corneal oedema resulting in visual impairment.

However, human CECs are unable to spontaneously divide and regenerate under physiological in vivo conditions. ${ }^{12}{ }^{13}$ In the early gestational period, human CECs are believed to be locked in the quiescent G1 phase of the cell cycle. ${ }^{14}$ This has been ascribed to various influences including cellular contact inhibition, ${ }^{16} 17$ the presence of inhibitors of mitosis (eg, transforming growth factor- $\beta 2),{ }^{16-19}$ or an absence of active stimuli from growth factors. ${ }^{17} 18$ Thus, the restoration of physiological function of the $\mathrm{CE}$ in diseased states can only depend on one of the three ways: (a) a replacement with an external source of healthy CECs, (b) the repair of impaired CECs or (c) the redistribution of remaining functional CECs to replace damaged or lost CECs. ${ }^{9}$ The current approach for treating corneal endothelial failure predominantly relies on the replenishment by an exogenous source of healthy CECs through various techniques of corneal transplantations. ${ }^{9}$ However, being dependent on a supply of transplantable grade donor corneas, the limited availability of such suitable donor tissues restricts the number of transplants that can be performed worldwide. ${ }^{20}$ Corneal transplantations can also be complicated by risks of allogeneic graft rejection and failure. ${ }^{21-23}$ Consequently, there is a drive in search for alternative therapies. ${ }^{9}$ These include cellbased approaches as a scalable source of human CECs or regenerative medicine, where damaged cells are repaired or existing functional CECs are made to redistribute to replace damaged or lost cells. ${ }^{9} 24$ These form the basis of potential future therapies for corneal endothelial replacement. In this review, we aim to illustrate the evolution of corneal endothelial replacement from past practices of full thickness penetrating keratoplasties, to present advanced endothelial keratoplasty (EK) techniques, to potential future novel therapies for corneal endothelial diseases that may be translated into clinical practice.

\section{CORNEAL ENDOTHELIAL REPLACEMENT: THE EARLY YEARS OF KERATOPLASTY}

Since Eduard Zirms' introduction of penetrating keratoplasty (PK) surgery in 1905, it has been the predominant technique to restore visual loss from various diseases of the cornea. ${ }^{25}$ In PK, all corneal layers of the recipient are replaced by a donor corneal graft, which is sutured to the recipient. ${ }^{9}$ It is an effective procedure in reversing corneal blindness. ${ }^{26}$ Thus, despite the redundant replacement of healthy 
anterior corneal tissues in PK with its known intra-operative and postoperative complications, this surgical procedure was deemed as the standard of care for treating corneal endothelial diseases throughout the 20th century. ${ }^{26} 27$

In the mid-1950s, Charles Tillet performed the first posterior lamellar keratoplasty (PLK) for corneal oedema, where he sutured a posterior corneal button to a diseased host. ${ }^{28}$ This marked the introduction of posterior lamellar or EK techniques, where diseased CE is selectively replaced, avoiding fullthickness PK procedures. ${ }^{9}$ In the original case report, the PLK procedure successfully reversed the patient's corneal oedema and the cornea remained clear after 1 year. ${ }^{28}$ However, the patient's vision was not restored due to postoperative high intraocular pressures caused by trapped air behind the iris. ${ }^{28}$ Shortly after, Jose Barraquer described a similar technique using a microkeratome-created laser in situ keratomileusis (LASIK) flap. ${ }^{29}$ This was followed by the trephination of the recipient's posterior lamellae comprising stromal tissue, Descemet's membrane (DM) and diseased CE. A donor endothelial graft was then fixed with sutures. The LASIK flap was subsequently repositioned and resutured. Nevertheless, although some success was achieved in replacing the diseased CE, these early PLK techniques were not widely adopted. This was partly due to the lack of appropriate surgical instruments needed to create a thin donor endothelial graft, which made these techniques difficult to perform. Complications and poor outcomes were also encountered as a result of a limited knowledge of endothelial cell physiology. Moreover, the need for suturing resulted in corneal astigmatism similar to PK. As a result, there were no significant developments of Tillet's and Barraquer's described PLK techniques for most of the second half of the 20th century. ${ }^{30}$

It was only until the late 1990s, when Gerrit Melles proposed an intrastromal approach for PLK that advancement in EK techniques rapidly followed. ${ }^{31} 32$ In Melles' PLK technique, a pocket was created via a corneoscleral incision to hold a donor endothelial graft without sutures. The graft was then transplanted through a limbal wound and was attached to the recipient's posterior corneal surface by means of an injected air bubble. Mark Terry subsequently adopted and modified Melles' PLK procedure, which was renamed as deep lamellar endothelial keratoplasty (DLEK). ${ }^{33}{ }^{34}$ Nevertheless, these PLK and DLEK techniques introduced were not universally adopted due to the high surgical demands of dissecting the host diseased cornea. ${ }^{30}$ The difficulties of obtaining a smooth recipientdonor interface by hand-dissection resulted in a compromise in bestachieved visual acuities and visual quality. ${ }^{35-37}$

\section{ENDOTHELIAL KERATOPLASTY: CURRENT APPROACHES Descemet's stripping endothelial keratoplasty (DSEK) and Descemet's stripping automated endothelial keratoplasty (DSAEK)}

In 2004, Melles further simplified his posterior lamellar approach by only selectively removing DM and CE from recipient's corneas, without the need to dissect stroma. ${ }^{38}$ This is known as 'descemetorhexis'. A pre-cut endothelial graft is subsequently inserted into the recipient's eye via a small corneal or scleral surgical wound and attached to the host cornea with an air or gas bubble. ${ }^{9}$ Using an internal approach and for preserving the host, posterior stroma creates a smooth surface on which the endothelial graft can be attached. This technique is known as Descemet's stripping endothelial keratoplasty (DSEK). Later, Gorovoy described the use of an automated microkeratome in the dissection of the donor graft to improve the graft-host interface. He called this procedure Descemet's stripping automated endothelial keratoplasty (DSAEK). ${ }^{39}$ Both DSEK and DSAEK techniques have since been widely adopted and performed worldwide. ${ }^{40}$

Since the introduction of these advanced EK techniques, a shift in the surgical management of corneal endothelial failure, away from full thickness PK, has been observed. ${ }^{41}$ Indeed, these EK techniques where diseased CE is selectively replaced have significantly transformed the field of corneal transplantation in treating corneal endothelial diseases over the past decade. Compared to PK, DSAEK procedures offer several clear advantages. ${ }^{22} 42$ Being minimally invasive, DSAEK avoids 'open-sky' situations following full thickness trephination of PKs and the associated sight-threatening risks of intraoperative suprachoroidal haemorrhage. ${ }^{943}$ In contrast to surgically induced weaknesses at the graft-host junctions seen in PK corneas, the biomechanical strengths of corneas that had undergone DSAEK are often maintained. ${ }^{44}$ This reduces the risk of devastating open globe injuries in the event of physical trauma. ${ }^{9}$ In addition to avoiding full-thickness transplantation, corneal sutures are often not required in DSAEK. There are thus lower risks of suture-related complications in DSAEKs including infectious keratitis and postoperative corneal astigmatism, the latter attributed to more rapid visual rehabilitation. ${ }^{9} 45-47$ Unlike PK, as the corneal profile is relatively well preserved in DSAEK, when concurrent cataract surgery is required, more accurate intraocular lens (IOL) power calculations can be achieved. ${ }^{9} 48$ Overall, the risks of allogeneic graft rejection rates are also observed to be lower in DSAEK grafts compared to $\mathrm{PK}^{22} 23$

Consequently, with its clear advantages, the DSAEK technique has become increasingly popular among corneal surgeons. In many institutions worldwide, DSAEK has now been adopted as the predominant procedure for reversing corneal blindness caused by endothelial dysfunction. ${ }^{40} 4950$ Since the introduction of DSEK/DSAEK surgeries, there have been noticeable developments in their techniques with the aims of improving postoperative outcomes. ${ }^{9}$ One example of such advancements lies in graft insertion techniques. The first DSEK grafts were inserted into the eye using a 60/40 'taco-folding' technique with the help of surgical forceps. ${ }^{30}$ Following insertion, grafts were then unfolded in the anterior chamber. However, significant ECD losses of up to $40 \%$ have been reported with this forceps folding technique. ${ }^{51}$ Since then, various innovative techniques to insert endothelial grafts have been proposed. ${ }^{52}$ These insertion methods have been shown to be less damaging to the CE. ${ }^{52-54}$ Such techniques include the use of IOL cartridges, sheets glide, or customised graft insertion devices to assist the surgeon in the intraocular transfer of DSAEK grafts. ${ }^{52-57}$ Some examples of customised graft insertion devices are the Endosaver (Ocular Systems, North Carolina USA), ${ }^{56}$ the Busin glide (Asico, Illinois, USA), ${ }^{53}$ the Neusidl Corneal Inserter (Fischer Surgical Missouri, USA), ${ }^{57}$ and the EndoGlide (Network Medical Products, North Yorkshire, UK). ${ }^{9} 54$ By maintaining the donor graft in an 'endothelium-down' orientation during insertion, these customised insertion devices aim to avoid unnecessary graft manipulation and damage to its CE when the graft is unfolded within the eye. ${ }^{53545}$ Unlike the 'taco-folding' technique, these devices also protect the DSAEK graft from endothelium-to-endothelium touch, and hence reducing the unnecessary loss of CECs. ${ }^{54}$ There are many variations in performing DSAEK. Figure 1 shows the authors' preferred DSAEK technique using the EndoGlide.

Research has also been focussed on evaluating the effects of reducing the thickness of the transplanted DSAEK grafts. Compared to thicker grafts, studies have reported improved visual outcomes when ultra-thin DSAEK grafts $(<100 \mu \mathrm{m})$ 


\section{DSAEK procedure}
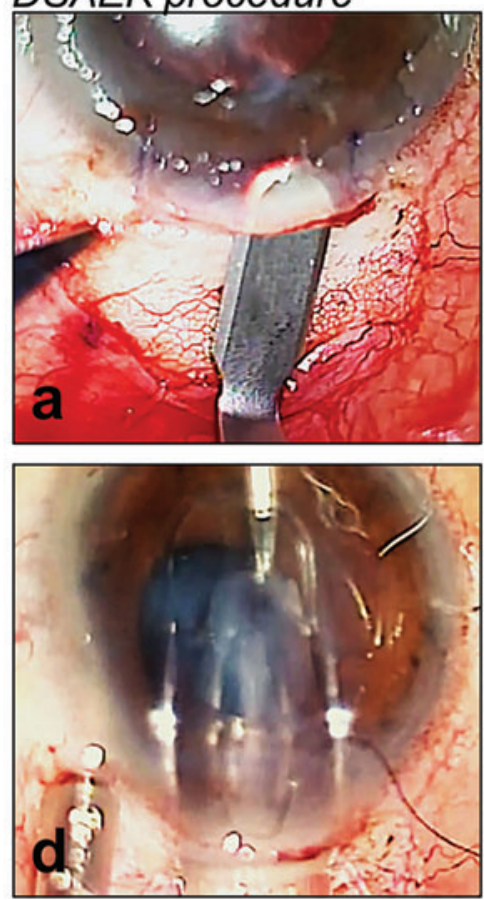
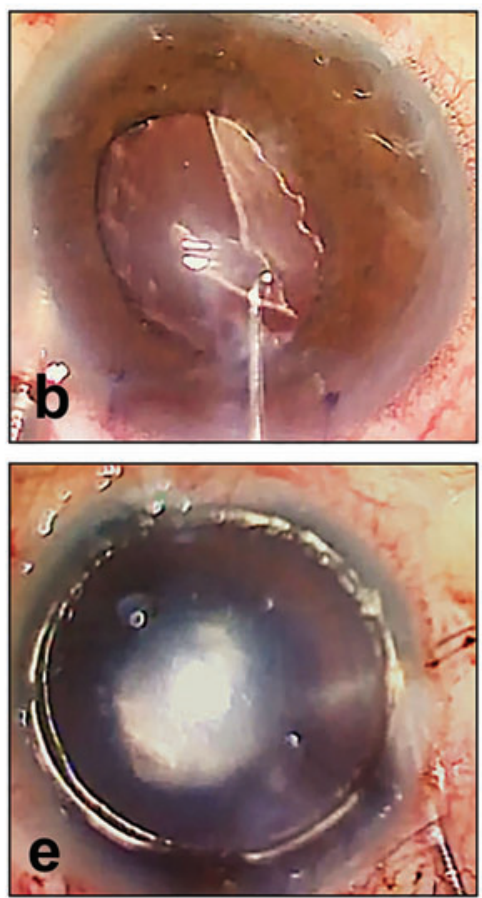
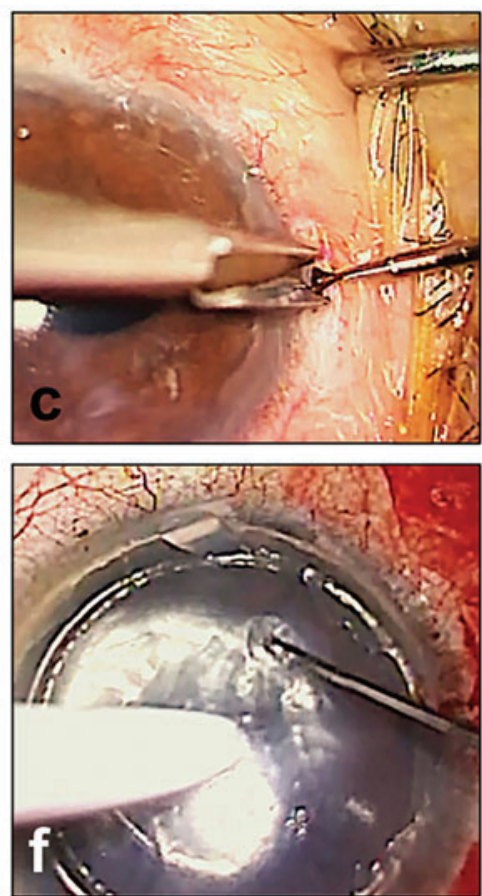

\section{DSAEK donor graft loading}
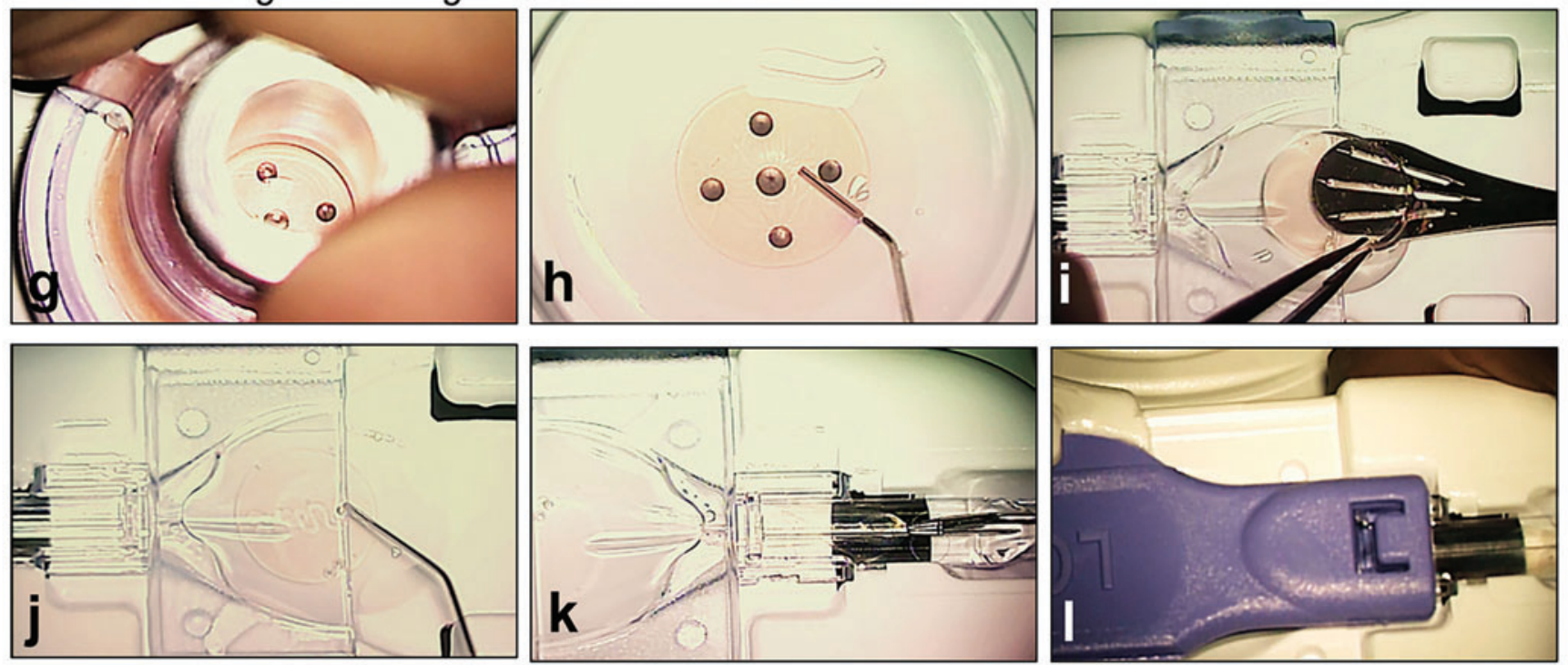

Figure 1 Authors' preferred surgical technique of Descemet's stripping automated endothelial keratoplasty (DSAEK) with the EndoGlide (Network Medical Products, Yorkshire, UK). (A) $4.5 \mathrm{~mm}$ scleral-tunnelled surgical wound; (B) descemetorhexis; (C) inferior peripheral iridectomy; (D) pre-cut DSAEK lenticule inserted into the anterior chamber via a pull-through technique; (E) injection of air for graft attachment; (F) opening of venting incisions to release fluid from the graft-host interface; (G) trephination of pre-cut graft; (H) fluid separation of DSAEK lenticule from anterior stromal cap; (I) DSAEK lenticule transferred to the EndoGlide; (J) ocular viscoelastic device coating to protect donor endothelial cells; (K) DSAEK lenticule is pulled into the EndoGlide using a customised micro-forceps; and (L) clip secured creating a 'closed system' during DSAEK graft insertion.

are transplanted. ${ }^{58} 59$ Several approaches have been introduced to reliably cut ultra-thin DSAEK grafts. ${ }^{9}$ One example is the 'double-pass technique' using a microkeratome, which involves a first $300 \mu \mathrm{m}$ debulking cut followed by a second refinement cut. ${ }^{6061}$ Other approaches to obtain ultra-thin DSAEK grafts include preconditioning donor tissues with airflow dehydration prior to the microkeratome cut $^{62}$ or graft dissection with the aid of a femtosecond laser. ${ }^{63}$
In spite of the considerable advancements in surgical techniques where good predictable results can be achieved, DSAEK does have its limitations. ${ }^{9}$ Undesirable hypermetropic outcomes can be caused by the presence of a stromal layer in transplanted DSAEK grafts. Visual quality may also be affected at the grafthost interface. ${ }^{64} 65$ The discrepancies in curvatures between recipient's posterior corneal surface and DSAEK donor lenticule may lead to folds as shown in figure 2 . 


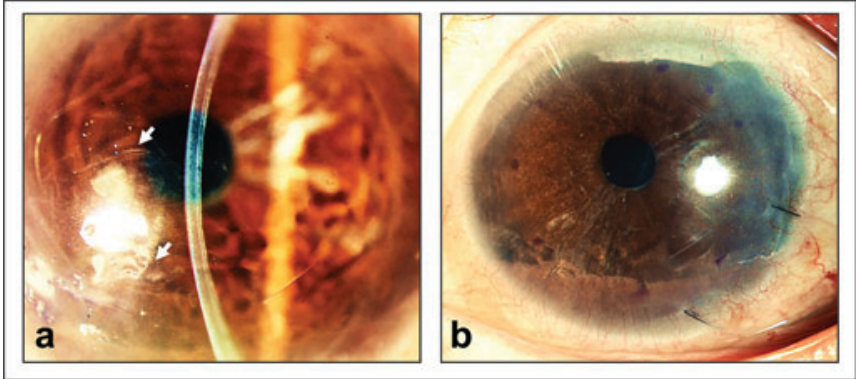

Figure 2 Optical quality degradation following Descemet's stripping automated endothelial keratoplasty (DSAEK). (A) Patient who received a DSAEK graft showing folds visible in the interface (arrows) between graft and recipient stroma resulting in visual symptoms; (B) the same patient who had a DSAEK graft exchanged with a Descemet's membrane endothelial keratoplasty (DMEK) graft showing the resolution of folds and corresponding improvement in optical quality.

\section{Descemet's membrane endothelial keratoplasty (DMEK)}

More recently, a significant development in EK surgery is the transplantation of donor DM with its endothelium without stroma. In 2006, Michael Tappin reported the use of purpose-made cannulas to transfer $7.5 \mathrm{~mm}$ donor endothelial discs with DM which were made to attach to recipient bare corneal stroma using an injected air bubble. ${ }^{66}$ Corneal oedema was reversed in all three cases reported using this procedure known as true endothelial cell (Tencell) transplantation. Around the same time, Melles introduced DMEK, a procedure which later became widely adopted by corneal surgeons worldwide. $^{21} 406768$ Like Tencell, a DMEK graft consisting of donor DM and endothelium is transplanted. ${ }^{9}$ Similar to DSAEK, air or gas tamponade was used to keep the DMEK graft adhered to the posterior corneal surface of the recipient (figure 2). By only replacing unhealthy corneal tissues, DMEK is an anatomically and functionally more accurate replacement of the diseased CE. ${ }^{9} 68$ Compared to DSAEK, DMEK has been reported to offer faster visual recovery and improved outcomes. ${ }^{69-74}$ Reports have also indicated lower rates of graft rejection following DMEK, ${ }^{23} 75$ and as such, with reduced need for steroids, a lower risk of glaucoma. ${ }^{76}$ Although endothelial cell loss following DMEK surgery has been reported to be higher than DSAEK in the initial follow-up period, ${ }^{71} 7778$ studies comparing DMEK to DSAEK with longer follow-up suggest that ECD loss is similar or better in DMEK. ${ }^{79}$ Nevertheless, in spite of these advantages of performing DMEK, corneal surgeons have been reluctant to take on DMEK as the primary surgical technique for the management of corneal endothelial failure. ${ }^{40} 41$ This trend is ascribed to the challenges encountered in DMEK surgery. ${ }^{9}$ Unlike DSAEK, a different set of skills with steeper learning curve are needed by the surgeon at each step of DMEK procedures. In DMEK, there are risks of tissue damage and wastage in donor graft harvesting, challenges in graft unfolding within the eye following graft insertion, and higher rates of complications such as graft detachments and iatrogenic failure. ${ }^{968}$

\section{Donor graft harvesting}

As the DM is approximately $10 \mu \mathrm{m}$ thin and highly friable, ${ }^{80}$ the success of DMEK graft donor preparation depends on consistent techniques that allow grafts to be harvested without damage and tissue wastage. ${ }^{9}$ Figure 3 illustrates DMEK graft harvesting by means of a 'submerged cornea using backgrounds away' (SCUBA) technique. ${ }^{81}$ Through graft harvesting under fluid, it allows easier tissue handling as surface tension on the free DM is negated. ${ }^{9}$ The initial step involves scoring and detaching the donor DM from the peripheral CE. This is followed by peeling of the DM prior to central trephination. During graft preparation, the visibility of the thin transparent DMEK graft can be enhanced using vital dyes such as Visionblue (D.O.R.C., Zuidland, The Netherlands). Other dyes, which give longer-lasting stains, such as Membrane Blue Dual (D.O. R.C., Zuidland, The Netherlands) can be applied prior to graft insertion to assist the surgeon in graft visualisation and orientation within the eye. ${ }^{82}$ Nevertheless, the exposure of the DMEK grafts to these vital dyes should be restricted as studies have reported timedependent toxic effects of these dyes to the CE. ${ }^{83}$

To prevent iatrogenic graft failure caused by an inadvertent 'up-side-down' graft, intraoperative orientation of the DMEK graft is essential. ${ }^{84}$ However, graft orientation can often be difficult following the intracameral transfer of the graft. In addition to the use of vital dyes, surgeons have also used other strategies such as asymmetrical markers created on harvested grafts to aid graft orientation. ${ }^{9}$ Some examples include the use of S-stamps ${ }^{85}$ or peripheral scalene triangular incisions. ${ }^{86}$

Other approaches have also been introduced to minimise the failure of graft preparation often caused by inadvertent tissue damage. For example, some investigators have employed the use of air or fluid to detach and harvest the donor DM from the posterior stroma ${ }^{87}{ }^{88}$ (figure $4 \mathrm{~A}$ ). There is also a growing trend in the use of DMEK grafts pre-stripped in the eye bank ${ }^{89-91}$ (figure 4B). By eliminating the need of the surgeon to prepare the donor graft, the use of pre-stripped DMEK grafts can reduce the learning curve of DMEK surgery; it allows the surgeon to concentrate on patient preparation and DMEK graft insertion, unscrolling and attachment. Furthermore, using pre-stripped DMEK grafts can potentially reduce surgical time, tissue wastage, cost and logistic requirements of DMEK graft harvesting performed by the surgeon. ${ }^{91-93}$ Although some investigators have suggested trends of reduced cell viability with pre-stripped DMEK grafts especially when stored in preservation media for a longer duration, ${ }^{94}$ most larger series investigating outcomes of pre-stripped DMEK have reported comparable results in conventional surgeon-prepared DMEK. ${ }^{90} 95-97$

\section{Donor graft insertion and unfolding}

Upon separation from the posterior stroma, a free-floating DM has a natural tendency to adopt a scrolled-configuration with its endothelium on its outer surface. ${ }^{98}$ This consistent 'endotheliumout' directional scrolling of DMEK graft tissues has been attributed to the elastin distribution within the DM-anterior dense band of elastin in the DM gives rise to a greater elasticity in its anterior compared to its posterior surface. ${ }^{98}$ It makes intracameral graft unfolding one of the most technically demanding stages in DMEK surgery. In particular, scrolls formed are often tighter in younger donors, and thus unfolding is thought to be even more challenging in these circumstances. ${ }^{99-101}$ 

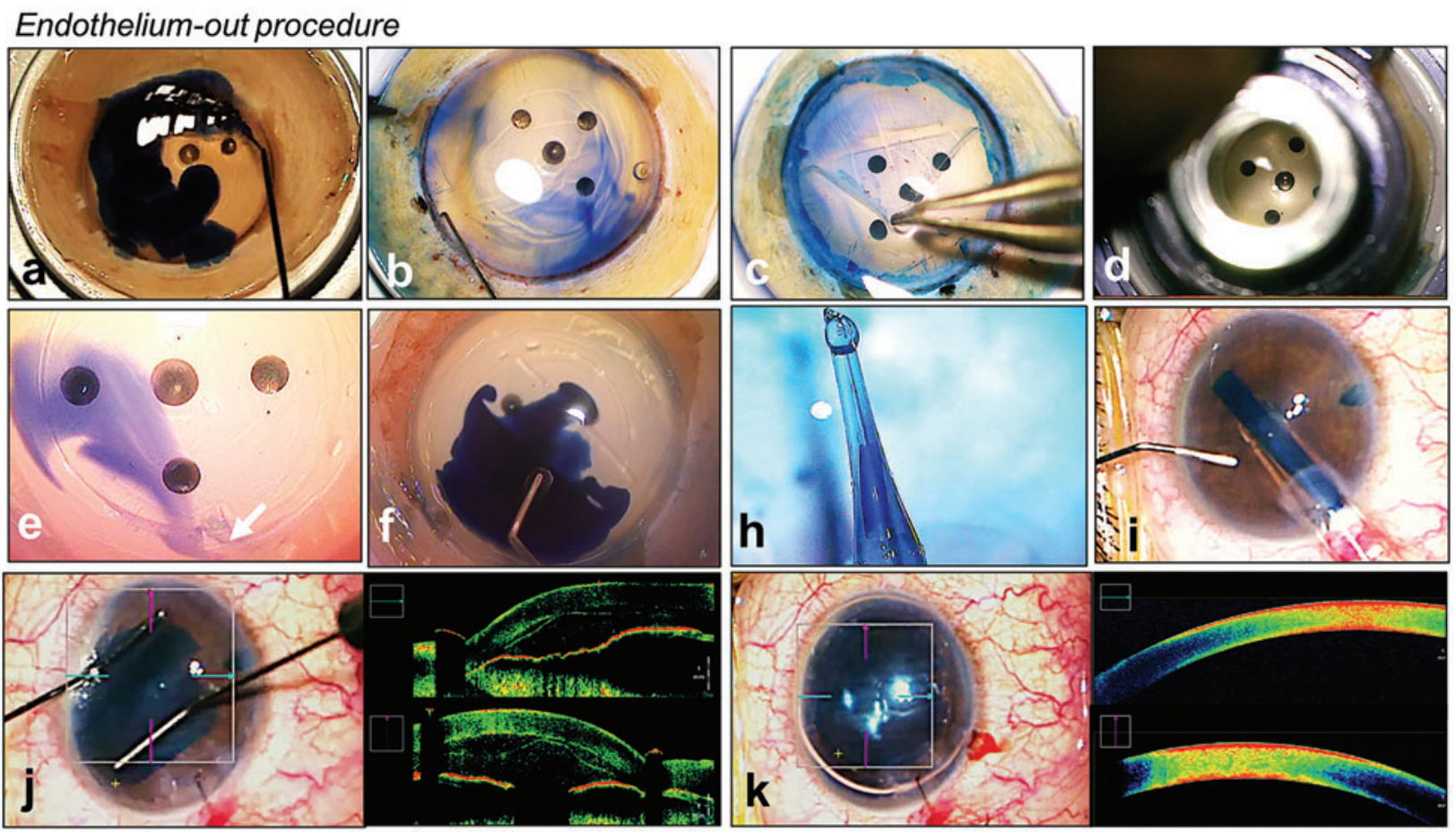

\section{Endothelium-in procedure}
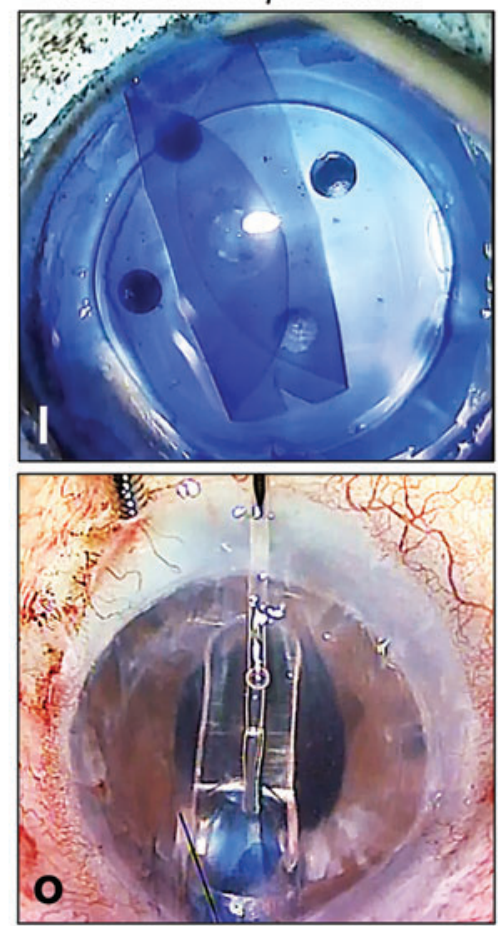
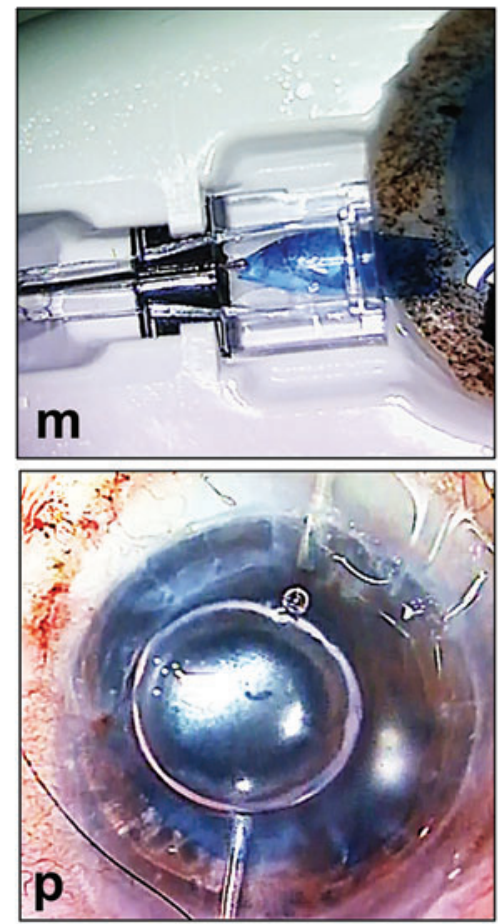
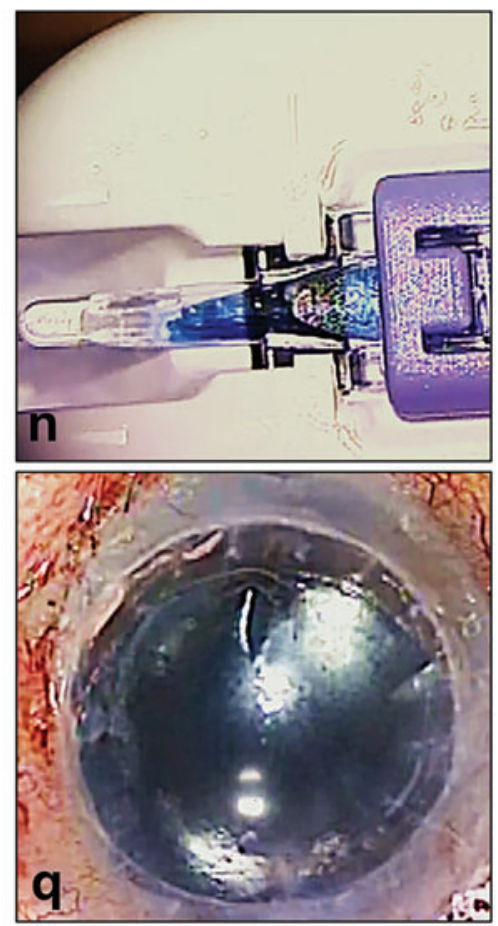

Figure 3 Authors' preferred surgical techniques of Descemet's membrane endothelial keratoplasty (DMEK). (A-K) Donor preparation using submerged cornea using backgrounds away (SCUBA) technique and 'endothelium-out' surgical technique of DMEK. (A) Visionblue (D.O.R.C., Zuidland, The Netherlands) to enhance Descemet's membrane (DM) visualisation; (B) corneal tissue scored in the periphery; (C) DM is peeled from periphery; (D) DMEK graft is trephined; (E) arrow showing surgically cut orientation mark (asymmetrical triangle); (F) Membrane Blue Dual (D.O.R.C., Zuidland, The Netherlands) applied to DMEK graft; (H) loading of graft into glass-injector; (I) intracameral injection of DMEK graft via a corneal surgical wound; (J) graft is unfolded using controlled taps over host cornea; (K) injection of air/gas for graft attachment; (L-Q) Surgical technique of 'endothelium-in' DMEK using a DMEK EndoGlide (Network Medical Products, Yorkshire, UK). (L) creating an 'endothelium-in' graft trifold; (M) donor loading into the DMEK EndoGlide using a pull-through technique; $(\mathrm{N})$ clip secured creating a 'closed system' during DMEK graft insertion; (0) graft inserted into the anterior chamber by a pull-through technique; $(\mathrm{P})$ air is injected whilst holding the donor to maintain orientation; $(\mathrm{Q})$ intracameral full air/gas fill for graft attachment. 

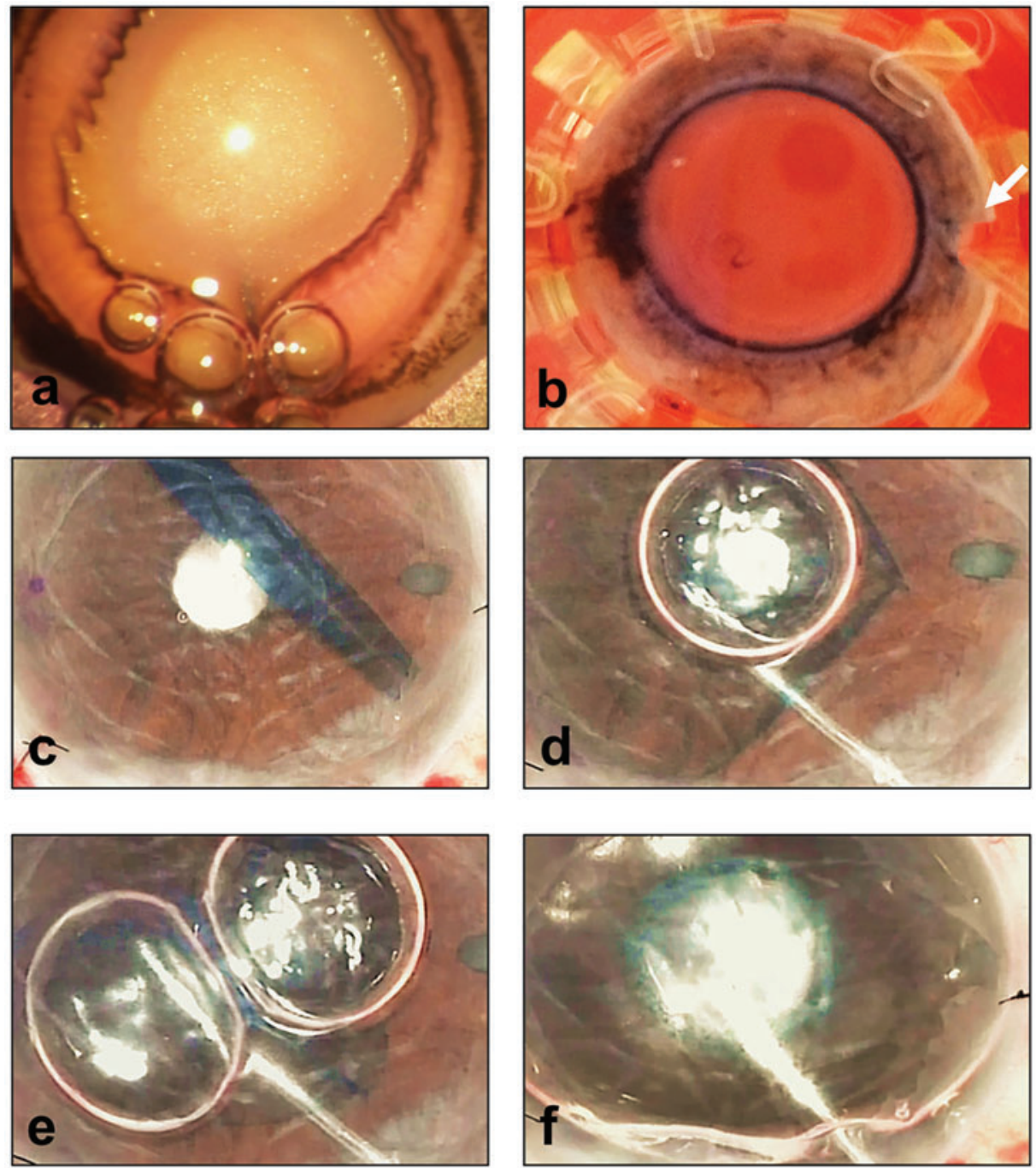

Figure 4 Strategies to improve success of Descemet's membrane endothelial keratoplasty (DMEK). (A) Air used to separate and detach Descemet's membrane from stroma for donor harvest; (B) eye bank pre-stripped DMEK graft; note the orientation S-stamp and mark on scleral rim indicating the unstripped area of the graft (arrow); (C-F) example of a tight scroll and use of air bubbles to assist the surgeon in opening up the graft (D, E) before full air tamponade (F).

Similar to DSAEK, a range of devices have been introduced to assist the surgeon in DMEK graft insertion. These devices shield the graft from endothelial damage when passing through the surgical wound. Examples of such devices include glass injections ${ }^{102} 103$ and the use of IOL cartridges. ${ }^{104} 105$ In the vast majority of techniques used in published studies, the DMEK graft is loaded such that its endothelium is on the outside ('endothelium-out') (figure 3A-K). In these 'endothelium-out' techniques, there is inevitable contact between graft endothelium and the inner wall of the insertion device which may potentially lead to ECD loss. There is also some evidence that plastic graft injectors correlated with higher postoperative graft detachment rates, compared to glass injectors. ${ }^{106} 107$ This observation has been explained by more variable ECD loss with plastic materials and intraoperative changes in the nature of DMEK grafts during insertion and unfolding, thought to be caused by electrostatic forces generated from plastic materials. ${ }^{106}$ However, not all studies have found this. ${ }^{108}$ Furthermore, in all 'endothelium-out' techniques, a scroll of DMEK graft is inserted into the eye in its entirety, leaving the surgeon to unscroll the free-floating graft in the anterior chamber. This can often be challenging, unpredictable, and time consuming. ${ }^{109}$ Compared to DSAEK, different surgical skills with steeper learning curve are required by the surgeon. ${ }^{110}$ The surgeon must learn various techniques to unfold a DMEK graft within the anterior chamber ${ }^{68111112}$ (figures 3A-K). Such techniques include methodological approaches to unfold double-scrolled grafts through a series of controlled taps on the corneal surface, the use of intracameral water currents to shift and orientate the graft, or air bubbles to assist the surgeon in opening tight scrolls. ${ }^{111} 112$ As these techniques of orientating and unscrolling a free-floating DMEK graft are reliant on normal anterior segment anatomies, structural abnormalities (eg, iris defects, aphakia, previous vitrectomies) can significantly increase the surgical complexity of the surgery. In cases such as tight graft scrolls or a very deep anterior chamber, the graft unfolding can also be technically challenging ${ }^{113}$ (figure 4C-F).

Recent publications have introduced 'endothelium-in' graft insertion techniques for DMEK surgery. ${ }^{114-117}$ After harvesting, the DMEK graft is folded often in a tri-fold, with its endothelium on its inner surface. This prevents the graft from naturally scrolling with its endothelium on the outer surface (figure 3L-Q). Such 'endothelium-in' techniques are thought to have the advantage of reducing donor CEC loss from inadvertent contact of graft endothelium on the luminal walls of insertion devices. Furthermore, in 'endothelium-in' techniques, the DMEK graft is inserted into the anterior chamber in the correct orientation with the endothelium facing 
downwards. Following insertion in an 'endothelium-in' configuration, the DMEK graft starts to unfold to adopt its natural 'endothelium-out' scroll, essentially 'assisting' the surgeon in graft unfolding. As such, the reliance on normal anterior segment structures (eg, intact iris diaphragm), important in 'endothelium-out' techniques, is circumvented in 'endothelium-in' techniques. These features of 'endothelium-in' techniques thus minimise the surgical challenges of graft orientation and unfolding of a free-floating scrolled graft within the eye. This makes DMEK surgery more controlled and predictable, especially in complex eyes with abnormal anatomies. 'Endothelium-in' techniques can be inserted into the eyes by (a) direct injection into the anterior chamber or (b) pulled into the eye using various 'pull-through devices' or IOL cartridges. Various 'pullthrough devices' have been designed to mimic DSAEK procedures, which are familiar to many corneal surgeons. ${ }^{114}$ An example of a 'pull-through endothelium-in' device is the DMEK EndoGlide (Network Medical Products, North Yorkshire, UK) ${ }^{9}$ (figure 3L-Q).

Since the introduction of DMEK surgery, variants of this surgical technique have been described. These include hemi-DMEK or quarter-DMEK ${ }^{118} 119$ and pre-Descemet's endothelial keratoplasty (PDEK). ${ }^{120}$ Hemi-DMEK or quarter-DMEK surgeries differ from standard DMEK only by the sizes and shapes of grafts transplanted into recipients. ${ }^{118} 119$ Compared to standard DMEK where one donor is used for one recipient, these techniques allow one donor to be used for two (hemi-DMEK) or four (quarter-DMEK) recipients, increasing the availability of donor endothelial tissues to more patients. Although the visual outcomes of hemi-DMEK and quarterDMEK have been reported to be comparable to standard DMEK in published small case series, there appears to be a larger drop in ECDs in the initial postoperative period in these newer techniques. ${ }^{118} 119$ Larger studies with longer duration of followup comparing the survival outcomes of hemi-DMEK or quarterDMEK to standard DMEK are required.

In 2014, the PDEK technique was introduced as a modification of DMEK. ${ }^{120}$ By including a pre-Descemet's layer, a PDEK graft is prevented from forming a natural scroll, unlike DMEK grafts. Thus, authors proposed that PDEK offers better control and reduces the need for intraocular manipulation to unfold a scrolled graft. ${ }^{120}$ A PDEK graft is harvested by intrastromal air injection to obtain a Type 1 big bubble which cleaves a plane between the preDescemet's layer and the rest of the corneal stroma. However, the ability to perform PDEK surgery is dependent on the reliability of achieving a Type 1 big bubble. ${ }^{9}$ Moreover, the size of the graft is also limited to approximately $7-8 \mathrm{~mm}$, the maximum diameter of a big bubble. It is worth noting that some consider the pre-Descemet's layer as an artificial formation of a stromal layer caused by pneumodissection, rather than a distinct anatomical structure. ${ }^{121}$

\section{FUTURE OF ENDOTHELIAL REPLACEMENT}

Conventional EK surgeries, the current standard of care for treating endothelial dysfunction, are increasingly successful in restoring vision. $^{2627122-125}$ (table 1). Nonetheless, the number of transplant surgeries that can be performed is restricted by the availability of suitable donor tissues. In a 2016 report, it was estimated that only $1.5 \%$ of the worldwide demands for corneal transplantations were being fulfilled. ${ }^{20}$ Furthermore, about a third of donor corneal tissues harvested were reported to be not suitable for transplant surgeries due to low ECD or abnormal donor infectious screen. ${ }^{20}$ Corneal transplantations are also associated with the requirements of specialised surgical expertise, high costs and the long-term risks of allogeneic graft rejection and failure.

With these limitations of corneal transplantations, research is thus focused on developing alternative approaches to replace

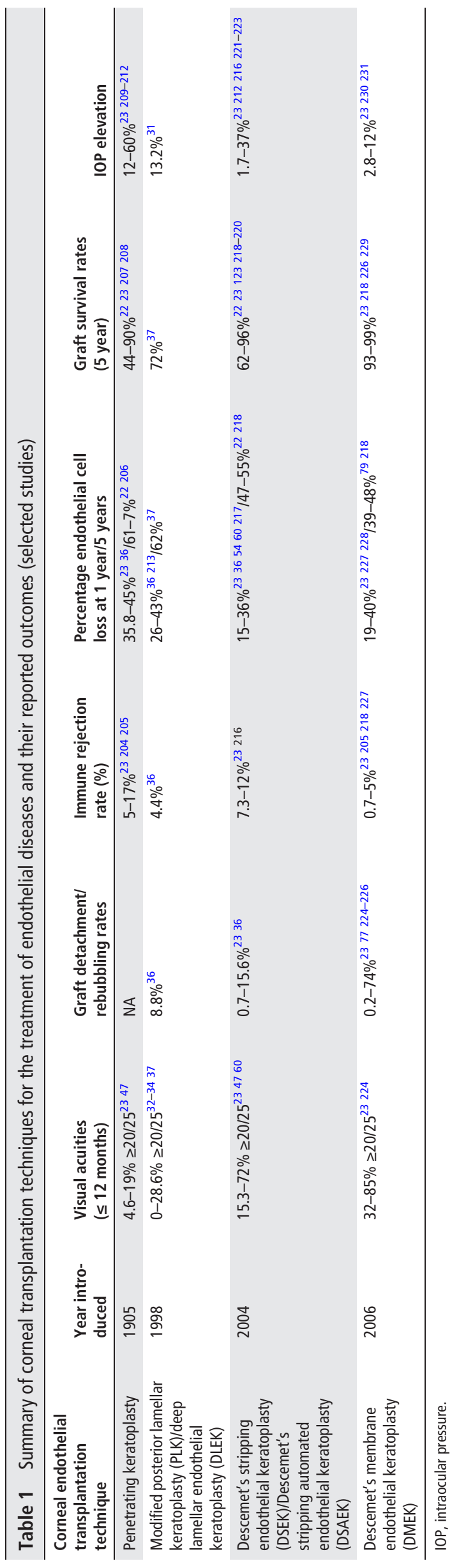


CECs in corneal endothelial diseases. ${ }^{24}$ These approaches include cell-based therapies and regenerative medicine. ${ }^{9}$ Cell-based therapies use the in vitro cultivation and propagation of CECs as an alternative scalable exogenous source of cells. In regenerative medicine, damaged cells are repaired or existing functional CECs are redistributed to replace damaged or lost cells. ${ }^{9}$

\section{Cell-based approaches to endothelial replacement}

Concepts of cell-based therapies

Cell-based therapies encompass the in vitro cultivation of primary native human CECs population from cadaveric donor corneas. ${ }^{126-128}$ With the propagation of functional CECs, the scalability of human CECs through cell cultures from a single donor cornea can yield sufficient CECs for the treatment of multiple patients; this is unlike conventional corneal transplantations where one donor is, in most situations, limited to the treatment of just one or, at best, a small number of recipients. ${ }^{24}$

In cell-based therapies, cultured CECs can subsequently be transferred to recipients' diseased corneas via either (1) cell-injection or (2) as a tissue-engineered construct. ${ }^{9} 24$ In cell-injection approach, cultured CECs are delivered by direct intracameral injection of the cells into the recipient. The recipient is then required to posture in a face-down position for 2-3 hours. This enables the CECs to settle and attach to the cornea of the recipient. ${ }^{24} 129-136$ (figure 5A-C) Some investigators have also described the role of ferromagnetic adherence using iron-endocytosed CECs, ${ }^{130}$ superparamagnetic microspheres, ${ }^{137}$ or magnetic nanoparticles, ${ }^{138}$ to aid in the distribution and attachment of CECs. Alternatively, cultured CECs may also be used to produce tissue-engineered endothelial constructs. $^{134139}$ (figure 5d) Engineered corneal endothelial grafts
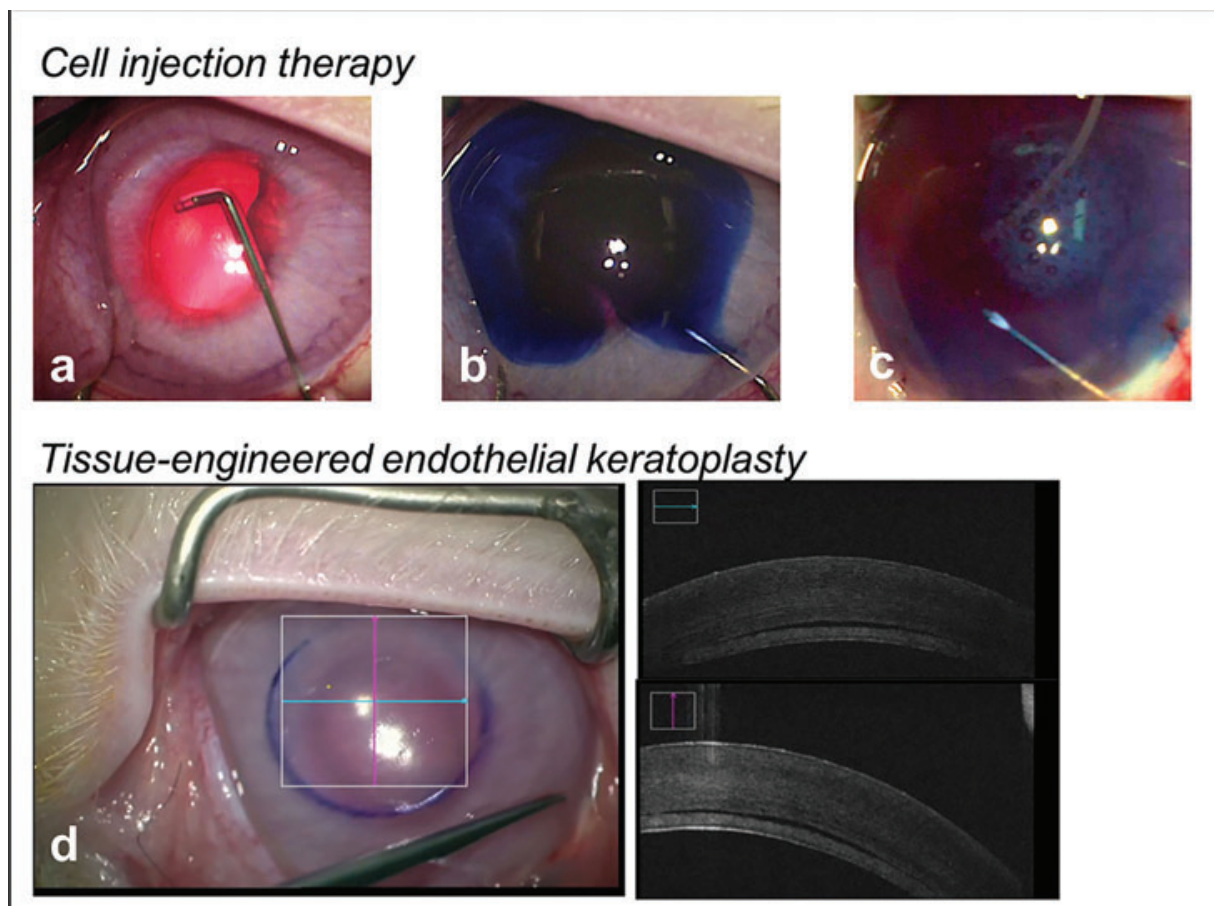

Descemet's membrane transplant

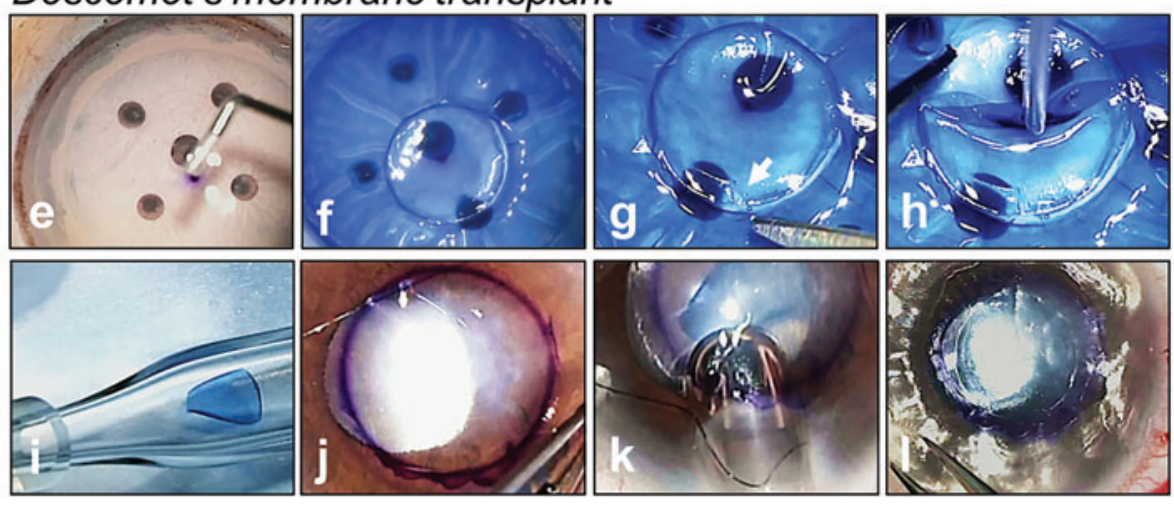

Figure 5 Novel therapies for the treatment of corneal endothelial diseases. (A-C) Cell injection therapy performed in a rabbit model of bullous keratopathy; silicone-tipped cannula is used to remove native corneal endothelial cells guided by trypan blue (A, B) followed by injection of cultured human corneal endothelial cells (C); (D) tissue-engineered endothelial keratoplasty performed in a rabbit model; (E-L) technique of the Descemet's membrane transplant (DMT); (E) removal of donor corneal endothelial cells by Descemet's membrane (DM) scrapping with a silicone tip cannula (SP125053, ASICO, USA); (F) trephination of DMT graft; note posterior surface of graft is stained blue with Visionblue (D.O.R.C, Zuidland, The Netherlands), showing its aceullarity; (G) orientation mark created (asymmetrical scalene triangle); (H) acellular DM disc is the loaded into a glass injector; (J) surgical marking on host cornea $(4-5 \mathrm{~mm})$ to indicate the central diseased area of DM stripping; $(K)$ intracameral injection of DMT graft via a corneal surgical wound; (L) intracameral full air/gas fill for graft attachment. 
are fashioned by high-density seeding of expanded CECs onto thin biological or synthetic scaffolds, and stabilised before transplantation into the eye. Reported examples of scaffolds studied included $\mathrm{DM},{ }^{140-150}$ amniotic membranes, ${ }^{151}$ collagen matrix, ${ }^{152}$ human corneal stromal discs, ${ }^{134} 139153154$ gelatin hydrogel discs ${ }^{155} 156$ and chitosan-based membranes. ${ }^{157}$ These tissue-engineered approaches allow the cells to be transplanted into the eye, similar to current EK techniques. ${ }^{24} 134139$

\section{Translation of cell-based therapies into clinical practice}

The translation of cell therapies using human-cultivated CECs into clinical trials requires specialised laboratory facilities and trained personnel with the appropriate expertise, specifically the ability to propagate CECs within an accredited Good Manufacturing Practices (GMP) environment. ${ }^{126-128} 139158$ Regulatory safety standards must also be met to use such cultured CECs in human clinical trials. ${ }^{139}$ In our recent work, we showed the ability to consistently propagate human CECs within a GMP environment. ${ }^{139}$ When we delivered these CECs into a rabbit model of bullous keratopathy through both intracameral cellinjection or tissue-engineered approaches, in vivo functionality was demonstrated by a reversal of corneal oedema. ${ }^{134}{ }^{139}$ In 2018, a pioneering clinical trial reporting the results of cellinjection therapy for corneal endothelial failure was published. ${ }^{135}$ Investigators demonstrated that the injection of cultivated CECs in growth medium augmented with rhoassociated protein kinase (ROCK) inhibitor, effectively treated corneal oedema and restored vision; outcomes were stable up to 24 months postoperatively. ${ }^{135}$ Further institutional review board-approved clinical trials investigating the clinical outcomes of tissue-engineered corneal endothelial transplantations are also underway (clinicaltrials.gov/ct2/show/NCT04319848). ${ }^{9} 139$

The availability of different modalities to deliver CECs is important. Each mode of delivery of CECs may be applicable to varying scenarios, depending on the pathophysiologies of the disease. We have previously demonstrated that an intact DM is essential for cell-injection therapies to work. ${ }^{134}$ Thus, cellinjection may not be suitable in all situations of corneal endothelial diseases. For instance, in the initial mild stages of diseases such as PBK or graft failure, where DMs are relatively spared, removal of CECs through DM scraping and replacing CECs via cellinjection may be the modality of choice. ${ }^{134}$ On the contrary, in advanced diseases with scarring of the DM, DM-stripping to remove abnormal DM is required. These patients may require other modalities of cell deliveries such as tissue-engineered grafts because cell-injection is known to be less effective without a DM. ${ }^{134}$ Likewise, in FECD, guttae and extracellular matrix excrescences on the DM can significantly affect vision. ${ }^{159}$ Our group has also shown that the height and density of guttae may affect the formation of a CEC monolayer ${ }^{160}$ and that large guttae can be toxic to injected endothelial cells. ${ }^{161}$ Thus, DM may need to be stripped in FECD with significant guttae and cell-injection may not be suitable. Future imaging techniques in development may allow us to evaluate the characteristics of these guttae to predict the success of cell-injection therapies. ${ }^{162}$

\section{Alternative sources of corneal endothelial cells for cell-based therapies}

Along with the expansion of primary CECs in culture, other studies have investigated alternative sources of CECs. Such alternative sources include the differentiation of adult cells into CECs phenotype. An example of such sources includes adult skinderived precursor cells, which are thought to be embryonic neural-crest-related precursors, exhibiting similar characteristics to neural-crest stem cells. ${ }^{163}$ As CECs are embryologically derived from the neural-crest, ${ }^{164} 165$ investigators have successfully produced CEC-like cells differentiated from adult skinderived precursor cells. ${ }^{166}$ The therapeutic effects of these cells were further demonstrated in different animal models of bullous keratopathy. ${ }^{166}$ Another example is the differentiation of neuralcrest cells and subsequently, CECs from induced pluripotent stem cells (iPSCs) derived from adult dermal fibroblasts. ${ }^{167}$ More recently, scientists have also used synthesised DM-like substrates to stimulate the differentiation of human mesenchymal stem cells into CEC-like cells through mechanotransductive effects. ${ }^{168}$ However, such alternative sources of CECs are at present largely experimental and culture protocols still require optimisation.

One key advantage of producing CECs from extraocular precursor cells to treat a patient with corneal endothelial failure is the ability to use non-ocular cells from the same patient with ocular disease. Such autologous sources of CECs would be valuable in minimising the risks of allogeneic rejection encountered in conventional keratoplasty surgeries. In the advent of genetic editing, such as the use of CRISPR endonucleases, treatment of corneal endothelial diseases using CECs derived from allogeneic sources may be feasible even in patients who have genetic predispositions to corneal disorders. ${ }^{169}$ An example is individuals with FECD who have the CTG trinucleotide repeat expansion mutation within the TCF4 gene. ${ }^{169-171}$

\section{Regenerative medicine approach to endothelial replacement} Role of Rho-associated kinases (ROCK) inhibitors in corneal diseases Rho-associated kinases (ROCK) belong to the AGC (cAMPdependent protein kinase/protein kinase G/protein kinase C) family of serine-threonine protein kinases. ${ }^{172-174}$ Due to the therapeutic potential of modifying cellular functions, ROCK-signalling pathway has become a popular field of research in recent years.

Activated ROCK leads to the phosphorylation of downstream targets. Principally, these targets regulate smooth muscle contraction through calcium ion sensitisation. They are important in controlling signal transduction pathways central to essential cellular function including stress fibres contraction, cell adhesion, cellular motility, cell proliferation, and apoptosis. ${ }^{175}$ ROCK also play a crucial role in modulating inflammatory cellular infiltration and migration. ${ }^{176}$ Furthermore, ROCK signalling has been reported to be involved in gene expression that leads to cell cycle regulation and differentiation. ${ }^{175}$ However, the role of ROCK in physiological pathways is cell specific and can vary depending on the cell line. The effects of inhibition of ROCK may also vary from one tissue to another. There is still little understanding of such differences.

In ophthalmology, ROCK inhibitors have been shown to have an effect in intraocular pressures lowering, important in the management of glaucoma. ${ }^{177} 178$ ROCK inhibitors have been shown to regulate conventional aqueous humour outflow facility through cell modifications, including cytoskeletal rearrangement, reduced cellular contraction and cell-cell contact in the trabecular meshwork and Schlemm canal. ${ }^{179-185}$ More recently, ROCK inhibitors have been investigated for their applications in regenerative therapies for corneal endothelial diseases. ${ }^{186-191}$ Unlike their effects on aqueous humour outflow, the inhibition of ROCK signalling in CECs has been shown to promote cell adhesion, inhibit apoptosis and enhance cellular proliferation in cultivated primate and human CECs. ${ }^{188} 190$ Clinical reports have also described the recovery of corneal endothelial function following transcorneal freezing of patients with corneal endothelial dysfunction and the administration of ROCK inhibitor eye drops. ${ }^{187} 191$ As mentioned above, in addition to the use of 
ROCK inhibitors in regenerative therapies, they also serve as important components of effective cultivation methods to propagate CECs for use in cell-based therapies. ${ }^{192}$

\section{Surgical techniques in regenerative medicine}

Two surgical techniques introduced recently that use regenerative medicine in the treatment of corneal endothelial diseases are Descemetorrhexis without endothelial keratoplasty (DWEK)/ Descemet's stripping only (DSO) and Descemet's membrane transplantation (DMT). ${ }^{9}$ Studies have indicated that corneal transplants performed for diseases in which healthy CECs are preserved in the peripheral cornea (eg, FECD) can achieve better graft survival compared to transplants performed for diseases causing widespread CEC loss (eg, pseudophakic bullous keratopathy). ${ }^{26}$ These observations have led to the concept of host CECs centripetal migration, which forms the underlying basis of DWEK/DSO and DMT. ${ }^{9}$

In 'DWEK' (or more recently accepted terminology of 'DSO'), ${ }^{193}$ diseased CE and DM in the central cornea of patients are removed to allow the central migration and redistribution of healthy peripheral CECs to restore endothelial function. ${ }^{194}$ This avoids the need for endothelial replacement through transplantation. However, clinical case series evaluating DSO for FECDs have reported variable results. ${ }^{195-199}$ DSO appears to be more reliable if only the central $4.00 \mathrm{~mm}$ of diseased DM is stripped ${ }^{197} 198$ or when patients received topical rho-associated protein kinase (ROCK) inhibitors. ${ }^{198} 199$ Larger randomised comparative studies with longer-term follow-up are required to establish the effectiveness of DSO as an intervention.

The importance of an intact DM to facilitate the central migration of CECs has since been described. ${ }^{200}$ Unlike DSO where the central corneal is left without a DM, following central stripping of diseased CE and DM, a decellularised DM is transplanted into the stripped area to enable CEC migration in DMT. ${ }^{9}$ Using this technique, the functionality of the $\mathrm{CE}$ to restore corneal clarity has been reported. $^{200201}$ This can allow for a larger descemetorhexis to be performed, that is, removal of a larger area of guttae.

To prepare a DMT graft, a donor cornea with ECD unsuitable for conventional transplantation (eg, <2000 cells $/ \mathrm{mm}^{2}$ ) undergoes a double freeze-thaw cycle. ${ }^{9}$ Subsequently, a manual removal of CECs from the donor cornea is performed using a siliconetipped cannula (catalogue number: SP-125053, ASICO, USA). An acellular DMT graft is then obtained via a donor harvesting technique used in DMEK (eg, SCUBA technique). As a larger population of peripheral host CECs following central descemtorhexis promote a more stable postmigration CEC population and faster recovery of cellular function, ${ }^{202}$ the size of the harvested DMT graft is kept small $(4.0-5.0 \mathrm{~mm}) .{ }^{9}$ As the size of the DMT graft is small, one can also harvest multiple grafts from a single donor cornea or even harvest DMT grafts from donor corneal rims whose central cornea has been harvested for conventional transplant surgeries. Such used donor corneal rims are currently discarded. Thus, one donor cornea can be used to treat more than one patient with endothelial disease. The procedure of DMT graft insertion is similar to standard DMEK surgery. Figure 5E$\mathrm{L}$ shows the procedure of DMT performed in FECD patient.

As the DMT graft is acellular, risks of immunological rejection and need for long-term immunosuppressive agents encountered in conventional transplantation are avoided. Additionally, donor tissues that are not suitable for conventional keratoplasties due to insufficient ECDs can be repurposed and used. ${ }^{9}$ Nevertheless, the success of regenerative medicine for corneal endothelial dysfunction does rely on appropriate patient selection. The first successful DMT was performed on a 56-year-old patient with FECD. ${ }^{201}$ As the migratory potential of CECs declines with advancing age, ${ }^{203}$ DMT performed on older patients may require additional measures to support CEC migration. These measures include the use of topical ROCK inhibitors (eg, Y-27 632, netarsudil, ripasudil) in DMT. ${ }^{9}$ The evidence in DMT, however, are based on animal data and case reports 200201 and studies with larger sample size and longer duration of follow-up are required.

It is worth noting that in regenerative medicine techniques, cells migrating from the periphery may be patients' diseased cells, such as FECD. Thus, disease phenotypes like guttae may still develop in the future. However, such regenerative approaches would have potentially delayed the age at which a corneal transplantation is required.

\section{CONCLUSION}

Over the past two decades, a paradigm shift from full-thickness penetrating keratoplasties to partial-thickness advanced endothelial keratoplasties has significantly improved the outcomes of corneal transplantations performed on patients with corneal endothelial diseases. Despite being effective in reversing corneal blindness, being donor dependent may mean that conventional corneal transplantation techniques will likely be replaced by novel alternatives, including scalable cell-based therapies and regenerative medicine. Further translational research and clinical trials are required to improve the specific therapeutic techniques and determine the longterm safety and efficacies of each novel therapy. Understanding the applicability of each of these treatment modalities according to the various underlying pathophysiologies may mean a more personalised approach to the future management of endothelial disease.

Correction notice This paper has been corrected since it was published online. There was a missing ' $\mathrm{S}$ ' initial in the last author's name, Jodhbir S Mehta.

Twitter Hon Shing Ong @onghonshing.

Contributors Conceptualisation and supervision: HSO, JM. Data curation/literature review: HSO. Formal nalysis and figures: HSO, JM. Writing draft, review and editing: HSO, MA, JM. All authors approved the manuscript.

Funding The authors have not declared a specific grant for this research from any funding agency in the public, commercial or not-for-profit sectors.

Disclaimer This review contains some concepts that have been previously presented in a book format (Ong HS, Mehta JS. Corneal Endothelial Reconstruction: Current and Future Approaches in Agarwal A, Narang P. Video Atlas of Anterior Segment Repair and Reconstruction-Managing Challenges in Cornea, Glaucoma, and Lens Surgery. Stuttgart, New York, Rio: Thieme Publishing Group, 2019:41-52).

Competing interests JSM holds a patent on the EndoGlide and receive royalties. The otherauthors have no other relevant affiliations or financial involvement with anyorganisation or entity with a financial interest in or financial conflict withthe subject matter or materials discussed in the manuscript apart from thosedisclosed.

Provenance and peer review Not commissioned; externally peer reviewed.

Open access This is an open access article distributed in accordance with the Creative Commons Attribution Non Commercial (CC BY-NC 4.0) license, which permits others to distribute, remix, adapt, build upon this work non-commercially, and license their derivative works on different terms, provided the original work is properly cited, appropriate credit is given, any changes made indicated, and the use is noncommercial. See: http://creativecommons.org/licenses/by-nc/4.0/.

\section{ORCID iDs}

Hon Shing Ong http://orcid.org/0000-0001-5475-8712

Marcus Ang http://orcid.org/0000-0003-3022-0795

\section{REFERENCES}

1 Bonanno JA. Molecular mechanisms underlying the corneal endothelial pump. Exp Eye Res 2012;95:2-7

2 Edelhauser HF. The balance between corneal transparency and edema: the proctor lecture. Invest Ophthalmol Vis Sci 2006;47:1754-67. 
3 Bahn CF, Glassman RM, MacCallum DK, et al. Postnatal development of corneal endothelium. Invest Ophthalmol Vis Sci 1986:27:44-51.

4 Bourne WM. Biology of the corneal endothelium in health and disease. Eye (Lond) 2003;17:912-8.

5 Nucci $P$, Brancato $R$, Mets MB, et al. Normal endothelial cell density range in childhood. Arch Ophthalmol 1990;108:247-8.

6 Bourne WM, Nelson LR, Hodge DO. Central corneal endothelial cell changes over a ten-year period. Invest Ophthalmol Vis Sci 1997;38:779-82.

7 Yee RW, Matsuda M, Schultz RO, et al. Changes in the normal corneal endothelial cellular pattern as a function of age. Curr Eye Res 1985;4:671-8.

8 Mahdy MA, Eid MZ, Mohammed MA, et al. Relationship between endothelial cell loss and microcoaxial phacoemulsification parameters in noncomplicated cataract surgery. Clin Ophthalmol 2012;6:503-10.

9 Ong HS, Mehta JS. Corneal endothelial reconstruction: current and future approaches in Agarwal A, Narang P. Video atlas of anterior segment repair and reconstruction-managing challenges in cornea, glaucoma, and lens surgery. Stuttgart, New York, Rio de Janeiro: Thieme Publishing Group, 2019:41-52.

10 Tuft SJ, Coster DJ. The corneal endothelium. Eye 1990;4:389-424

11 McCartney MD, Wood TO, McLaughlin BJ. Freeze-fracture label of functional and dysfunctional human corneal endothelium. Curr Eye Res 1987;6:589-97.

12 Murphy C, Alvarado J, Juster R, et al. Prenatal and postnatal cellularity of the human corneal endothelium. A quantitative histologic study. Invest Ophthalmol Vis Sci 1984;25:312-22

13 Edelhauser HF. The resiliency of the corneal endothelium to refractive and intraocular surgery. Cornea 2000;19:263-73.

14 Joyce NC, Meklir B, Joyce SJ, et al. Cell cycle protein expression and proliferative status in human corneal cells. Invest Ophthalmol Vis Sci 1996;37:645-55.

15 Joyce NC, Navon SE, Roy S, et al. Expression of cell cycle-associated proteins in human and rabbit corneal endothelium in situ. Invest Ophthalmol Vis Sci 1996;37:1566-75.

16 Joyce NC, Harris DL, Mello DM. Mechanisms of mitotic inhibition in corneal endothelium: contact inhibition and TGF-beta2. Invest Ophthalmol Vis Sci 2002;43:2152-9.

17 Joyce NC. Proliferative capacity of corneal endothelial cells. Exp Eye Res 2012;95:16-23.

18 Lu J, Lu Z, Reinach P, et al. TGF-beta2 inhibits AKT activation and FGF-2-induced corneal endothelial cell proliferation. Exp Cell Res 2006;312:3631-40.

19 Joyce NC, Harris DL, Zieske JD. Mitotic inhibition of corneal endothelium in neonatal rats. Invest Ophthalmol Vis Sci 1998;39:2572-83.

20 Gain $\mathrm{P}$, Jullienne $\mathrm{R}, \mathrm{He} Z$, et al. Global survey of corneal transplantation and eye banking. JAMA Ophthalmol 2016;134:167-73.

21 Australian Corneal Graft Registry C. The Australian graft registry 2018 report. Secondary the Australian graft registry 2018 report 2018. Available https://dspace. flinders.edu.au/xmlui/bitstream/handle/2328/37917/ACGR\%202018\%20Report. pdf? sequence $=3$ \&isAllowed $=y$

22 Ang M, Soh Y, Htoon HM, et al. Five-year graft survival comparing Descemet stripping automated endothelial keratoplasty and penetrating keratoplasty. Ophthalmology 2016;123:1646-52.

23 Woo JH, Ang M, Htoon HM, et al. Descemet membrane endothelial keratoplasty versus Descemet stripping automated endothelial keratoplasty and penetrating keratoplasty. Am J Ophthalmol 2019;207:288-303.

24 Fuest M, Yam GH, Peh GS, et al. Advances in corneal cell therapy. Regen Med 2016;11:601-15.

25 Zirm EK. Eine erfolgreiche totale Keratoplastik (A successful total keratoplasty). 1906. Refract Corneal Surg 1989;5:258-61.

26 Coster DJ, Lowe MT, Keane MC, et al. Australian Corneal Graft Registry C. A comparison of lamellar and penetrating keratoplasty outcomes: a registry study. Ophthalmology 2014;121:979-87.

27 Tan DT, Dart JK, Holland EJ, et al. Corneal transplantation. Lancet 2012;379:1749-61.

28 Tillett CW. Posterior lamellar keratoplasty. Am J Ophthalmol 1956;41:530-3.

29 Barraquer J. Lamellar keratoplasty. (Special techniques). Ann Ophthalmol 1972;4:437-69

30 Guell JL, El Husseiny MA, Manero F, et al. Historical review and update of surgical treatment for corneal endothelial diseases. Ophthalmol Ther 2014;3(1-2):1-15.

31 Melles GR, Eggink FA, Lander F, et al. A surgical technique for posterior lamellar keratoplasty. Cornea 1998;17:618-26.

32 Melles GR, Lander F, van Dooren BT, et al., Preliminary clinical results of posterior lamellar keratoplasty through a sclerocorneal pocket incision. Ophthalmology 2000;107:1850-6. discussion 57.

33 Terry MA, Ousley PJ. Deep lamellar endothelial keratoplasty in the first United States patients: early clinical results. Cornea 2001;20:239-43.

34 Terry MA, Ousley PJ. Rapid visual rehabilitation after endothelial transplants with deep lamellar endothelial keratoplasty (DLEK). Cornea 2004;23:143-53.

35 Bahar I, Sansanayudh W, Levinger E, et al. Posterior lamellar keratoplasty: comparison of deep lamellar endothelial keratoplasty and Descemet stripping automated endothelial keratoplasty in the same patients: a patient's perspective. $\mathrm{Br}$ J Ophthalmol 2009;93:186-90.
36 Bahar I, Kaiserman I, McAllum P, et al. Comparison of posterior lamellar keratoplasty techniques to penetrating keratoplasty. Ophthalmol 2008;115:1525-33.

37 Mashor RS, Kaiserman I, Kumar NL, et al. Deep lamellar endothelial keratoplasty: up to 5-year follow-up. Ophthalmol 2010;117:680-6.

38 Melles GR, Wijdh RH, Nieuwendaal CP. A technique to excise the Descemet membrane from a recipient cornea (descemetorhexis). Cornea 2004;23:286-8.

39 Gorovoy MS. Descemet-stripping automated endothelial keratoplasty. Cornea 2006;25:886-9.

40 EBAA. Eye banking statistical report. Secondary eye banking statistical report 2018 Available https://restoresight.org/what-we-do/publications/statistical-report/

41 Park CY, Lee JK, Gore PK, et al. Keratoplasty in the United States: a 10-year review from 2005 through 2014. Ophthalmol 2015;122:2432-42.

42 Ang M, Htoon HM, Cajucom-Uy HY, et al. Donor and surgical risk factors for primary graft failure following Descemet's stripping automated endothelial keratoplasty in Asian eyes. Clin Ophthalmol 2011:5:1503-8.

43 Ang M, Mehta JS, Lim F, et al. Endothelial cell loss and graft survival after Descemet's stripping automated endothelial keratoplasty and penetrating keratoplasty. Ophthalmol 2012;119:2239-44.

44 Ang M, Mehta JS, Anshu A, et al. Endothelial cell counts after Descemet's stripping automated endothelial keratoplasty versus penetrating keratoplasty in Asian eyes. Clin Ophthalmol 2012;6:537-44.

45 Ang M, Lim F, Htoon HM, et al. Visual acuity and contrast sensitivity following Descemet stripping automated endothelial keratoplasty. Br J Ophthalmol 2016:100:307-11.

46 Koenig SB, Covert DJ, Dupps WJ Jr., et al. Visual acuity, refractive error, and endothelial cell density six months after Descemet stripping and automated endothelial keratoplasty (DSAEK). Cornea 2007;26:670-4

47 Fuest M, Ang M, Htoon HM, et al. Long-term visual outcomes comparing Descemet stripping automated endothelial keratoplasty and penetrating keratoplasty. Am J Ophthalmol 2017;182:62-71.

48 Terry MA, Shamie N, Chen ES, et al. Endothelial keratoplasty for Fuchs' dystrophy with cataract: complications and clinical results with the new triple procedure. Ophthalmol 2009:116:631-9.

49 Bose S, Ang M, Mehta JS, et al. Cost-effectiveness of Descemet's stripping endothelia keratoplasty versus penetrating keratoplasty. Ophthalmo/ 2013:120:464-70.

50 Tan D, Ang M, Arundhati A, et al. Development of selective lamellar keratoplasty within an Asian corneal transplant program: the Singapore corneal transplant study (an American Ophthalmological Society Thesis). Trans Am Ophthalmol Soc 2015;113:T10.

51 Mehta JS, Por YM, Poh R, et al. Comparison of donor insertion techniques for Descemet stripping automated endothelial keratoplasty. Arch Ophthalmol 2008:126:1383-8.

52 Ang M, Saroj L, Htoon HM, et al. Comparison of a donor insertion device to sheets glide in Descemet stripping endothelial keratoplasty: 3-year outcomes. Am J Ophthalmol 2014;157:1163-69 e3.

53 Busin M, Bhatt PR, Scorcia V. A modified technique for Descemet membrane stripping automated endothelial keratoplasty to minimize endothelial cell loss. Arch Ophthalmol 2008;126:1133-7.

54 Khor WB, Mehta JS, Tan DT. Descemet stripping automated endothelial keratoplasty with a graft insertion device: surgical technique and early clinical results. Am J Ophthalmol 2011;151:223-32 e2.

55 Wendel LJ, Goins KM, Sutphin JE, et al. Comparison of bifold forceps and cartridge injector suture pull-through insertion techniques for Descemet stripping automated endothelial keratoplasty. Cornea 2011;30:273-6.

56 Tsatsos M, Athanasiadis I, Kopsachilis N, et al. Comparison of the endosaver with noninjector techniques in Descemet's stripping endothelial keratoplasty. Indian I Ophthalmol 2017:65:1133-7.

57 Kobayashi A, Yokogawa H, Sugiyama K. Clinical results of the Neusidl Corneal Inserter((R)), a new donor inserter for Descemet's stripping automated endothelial keratoplasty, for small Asian eyes. Ophthalmic Surg Lasers Imaging 2012:43:311-8

$58 \mathrm{KD} \mathrm{N}, J \mathrm{M} \mathrm{B}, \mathrm{EJ} \mathrm{H}$. Comparison of central corneal graft thickness to visual acuity outcomes in endothelial keratoplasty. Cornea 2011;30:388-91.

59 Shinton AJ, Tsatsos M, Konstantopoulos A, et al. Impact of graft thickness on visual acuity after Descemet's stripping endothelial keratoplasty. Br J Ophthalmol 2012;96:246-9.

60 Busin M, Madi S, Santorum P, et al. Ultrathin Descemet's stripping automated endothelial keratoplasty with the microkeratome double-pass technique: two-year outcomes. Ophthalmol 2013;120:1186-94.

61 Busin M, Patel AK, Scorcia V, et al. Microkeratome-assisted preparation of ultrathin grafts for Descemet stripping automated endothelial keratoplasty. Invest Ophthalmol Vis Sci 2012;53:521-4.

62 Thomas PB, Mukherjee AN, O'Donovan D, et al. Preconditioned donor corneal thickness for microthin endothelial keratoplasty. Cornea 2013;32: e173-8.

63 Rosa AM, Silva MF, Quadrado MJ, et al. Femtosecond laser and microkeratome-assisted Descemet stripping endothelial keratoplasty: first clinical results. Br J Ophthalmol 2013;97:1104-7. 
64 Patel SV, Baratz KH, Hodge DO, et al. The effect of corneal light scatter on vision after Descemet stripping with endothelial keratoplasty. Arch Ophthalmol 2009; 127:153-60.

65 Droutsas K, Lazaridis A, Giallouros E, et al. Scheimpflug densitometry after DMEK versus DSAEK-two-year outcomes. Cornea 2018;37:455-61.

66 Tappin M. A method for true endothelial cell (Tencell) transplantation using a custom-made cannula for the treatment of endothelial cell failure. Eye (Lond) 2007;21:775-9.

67 Melles GR, Ong TS, Ververs B, et al. Descemet membrane endothelial keratoplasty (DMEK). Cornea 2006:25:987-90.

68 Ang M, Wilkins MR, Mehta JS, et al. Descemet membrane endothelial keratoplasty. Br J Ophthalmol 2016;100:15-21.

69 Singh A, Zarei-Ghanavati M, Avadhanam V, et al. Systematic review and meta-analysis of clinical outcomes of Descemet membrane endothelial keratoplasty versus descemet stripping endothelial keratoplasty/Descemet stripping automated endothelial keratoplasty. Cornea 2017;36:1437-43.

70 Droutsas K, Lazaridis A, Papaconstantinou D, et al. Visual outcomes after Descemet membrane endothelial keratoplasty versus Descemet stripping automated endothelial keratoplasty-comparison of specific matched pairs. Cornea 2016:35:765-71.

71 Tourtas T, Laaser K, Bachmann BO, et al. Descemet membrane endothelial keratoplasty versus Descemet stripping automated endothelial keratoplasty. Am J Ophthalmol 2012;153:1082-90 e2.

72 Maier AK, Gundlach E, Gonnermann J, et al. Retrospective contralateral study comparing Descemet membrane endothelial keratoplasty with Descemet stripping automated endothelial keratoplasty. Eye (Lond) 2015:29:327-32.

73 Goldich Y, Showail M, Avni-Zauberman N, et al. Contralateral eye comparison of Descemet membrane endothelial keratoplasty and Descemet stripping automated endothelial keratoplasty. Am J Ophthalmol 2015;159:155-9 e1.

74 Guerra FP, Anshu A, Price MO, et al. Endothelial keratoplasty: fellow eyes comparison of Descemet stripping automated endothelial keratoplasty and Descemet membrane endothelial keratoplasty. Cornea 2011;30:1382-6.

75 Marques RE, Guerra PS, Sousa DC, et al. DMEK versus DSAEK for Fuchs' endothelial dystrophy: a meta-analysis. Eur J Ophthalmol 2018;1120672118757431.

76 Ang M, Sng CCA. Descemet membrane endothelial keratoplasty and glaucoma. Curr Opin Ophthalmol 2018;29:178-84.

77 Price MO, Giebel AW, Fairchild KM, et al. Descemet's membrane endothelial keratoplasty: prospective multicenter study of visual and refractive outcomes and endothelial survival. Ophthalmology 2009;116:2361-8.

78 Dirisamer M, Ham L, Dapena I, et al. Efficacy of Descemet membrane endothelial keratoplasty: clinical outcome of 200 consecutive cases after a learning curve of 25 cases. Arch Ophthalmol 2011:129:1435-43.

79 Feng MT, Price MO, Miller JM, et al. Air reinjection and endothelial cell density in Descemet membrane endothelial keratoplasty: five-year follow-up. J Cataract Refract Surg 2014;40:1116-21.

80 Johnson DH, Bourne WM, Campbell RJ. The ultrastructure of Descemet's membrane. I. Changes with age in normal corneas. Arch Ophthalmol 1982;100:1942-7.

81 Brissette A, Conlon R, Teichman JC, et al. Evaluation of a new technique for preparation of endothelial grafts for Descemet membrane endothelial keratoplasty. Cornea 2015;34:557-9.

82 Tan TE, Devarajan $\mathrm{K}$, Seah $\mathrm{XY}$, et al. Lamellar dissection technique for Descemet membrane endothelial keratoplasty graft preparation. Cornea 2020;39:23-9.

83 Weber IP, Rana M, Thomas PBM, et al. Effect of vital dyes on human corneal endothelium and elasticity of Descemet's membrane. PLoS One 2017;12:e184375.

84 Ang M, Dubis AM, Wilkins MR. Descemet membrane endothelial keratoplasty: intraoperative and postoperative imaging spectral-domain optical coherence tomography. Case Rep Ophthalmol Med 2015:2015:506251.

85 Veldman PB, Dye PK, Holiman JD, et al. The S-stamp in Descemet membrane endothelial keratoplasty safely eliminates upside-down graft implantation. Ophthalmology 2016;123:161-4

86 Bhogal M, Maurino V, Allan BD. Use of a single peripheral triangular mark to ensure correct graft orientation in Descemet membrane endothelial keratoplasty. J Cataract Refract Surg 2015;41:2022-4.

87 Muraine M, Gueudry J, He Z, et al. Novel technique for the preparation of corneal grafts for Descemet membrane endothelial keratoplasty. Am J Ophthalmol 2013:156:851-9.

88 Zarei-Ghanavati S, Zarei-Ghanavati M, Ramirez-Miranda A, Air-assisted donor preparation for DMEK. J Cataract Refract Surg 2011;37:1372. author reply 72.

89 Chamani T, Javadi MA, Kanavi MR. Trephine- and dye-free technique for eye bank preparation of pre-stripped Descemet membrane endothelial keratoplasty tissue. Cell Tissue Bank 2019:20:321-6.

90 Deng SX, Sanchez PJ, Chen L. Clinical outcomes of Descemet membrane endothelial keratoplasty using eye bank-prepared tissues. Am J Ophthalmol 2015;159:590-6.

91 Parekh M, Baruzzo M, Favaro E, et al. Standardizing Descemet membrane endothelial keratoplasty graft preparation method in the eye bank-experience of 527 Descemet membrane endothelial keratoplasty tissues. Cornea 2017;36:1458-66.
92 Terry MA. Endothelial keratoplasty: a comparison of complication rates and endothelial survival between precut tissue and surgeon-cut tissue by a single DSAEK surgeon. Trans Am Ophthalmol Soc 2009;107:184-91.

93 Yong KL, Nguyen HV, Cajucom-Uy HY, et al. Cost minimization analysis of precut cornea grafts in Descemet stripping automated endothelial keratoplasty. Medicine (Baltimore) 2016:95:e2887.

94 Menzel-Severing J, Walter P, Plum WJ, et al. Assessment of corneal endothelium during continued organ culture of pre-stripped human donor tissue for DMEK surgery. Curr Eye Res 2018;43:1439-44.

95 Newman LR, DeMill DL, Zeidenweber DA, et al. Preloaded Descemet membrane endothelial keratoplasty donor tissue: surgical technique and early clinical results. Cornea 2018;37:981-6

96 Regnier M, Auxenfans C, Maucort-Boulch D, et al. Eye bank prepared versus surgeon cut endothelial graft tissue for Descemet membrane endothelial keratoplasty: an observational study. Medicine (Baltimore) 2017:96:e6885.

97 Rickmann A, Wahl S, Hofmann N, et al. Precut DMEK using dextran-containing storage medium is equivalent to conventional DMEK: a prospective pilot study. Cornea 2019:38:24-9.

98 Mohammed I, Ross AR, Britton JO, et al. Elastin content and distribution in endothelial keratoplasty tissue determines direction of scrolling. Am J Ophthalmol 2018;194:16-25.

99 Kruse FE, Schrehardt US, Tourtas T. Optimizing outcomes with Descemet's membrane endothelial keratoplasty. Curr Opin Ophthalmol 2014;25:325-34.

100 Bennett A, Mahmoud S, Drury D, et al. Impact of donor age on corneal endothelium-Descemet membrane layer scroll formation. Eye Contact Lens 2015:41:236-9.

101 Schaub F, Enders P, Zachewicz J, et al. Impact of donor age on Descemet membrane endothelial keratoplasty outcome: evaluation of donors aged $17-55$ years. Am J Ophthalmol 2016;170:119-27.

102 Dapena I, Moutsouris K, Droutsas K, et al. Standardized "no-touch" technique for Descemet membrane endothelial keratoplasty. Arch Ophthalmol 2011;129:88-94.

103 Arnalich-Montiel F, Munoz-Negrete FJ, De Miguel MP. Double port injector device to reduce endothelial damage in DMEK. Eye (Lond) 2014:28:748-51.

104 Kruse FE, Laaser K, Cursiefen C, et al. A stepwise approach to donor preparation and insertion increases safety and outcome of Descemet membrane endothelial keratoplasty. Cornea 2011;30:580-7

105 Kim EC, Bonfadini G, Todd L, et al. Simple, inexpensive, and effective injector for Descemet membrane endothelial keratoplasty. Cornea 2014;33:649-52.

106 Monnereau C, Quilendrino R, Dapena I, et al. Multicenter study of Descemet membrane endothelial keratoplasty: first case series of 18 surgeons. JAMA Ophthalmol 2014;132:1192-8.

107 Dirisamer M, van Dijk K, Dapena I, et al. Prevention and management of graft detachment in Descemet membrane endothelial keratoplasty. Arch Ophthalmol 2012;130:280-91

108 Oellerich S, Baydoun L, Peraza-Nieves J, et al. Multicenter study of 6-month clinical outcomes after Descemet membrane endothelial keratoplasty. Cornea 2017;36:1467-76.

109 Maier AK, Gundlach E, Schroeter J, et al. Influence of the difficulty of graft unfolding and attachment on the outcome in Descemet membrane endothelial keratoplasty. Graefes Arch Clin Exp Ophthalmol 2015;253:895-900.

110 Phillips PM, Phillips LJ, Muthappan V, et al. Experienced DSAEK surgeon's transition to DMEK: outcomes comparing the last 100 DSAEK surgeries with the first 100 DMEK surgeries exclusively using previously published techniques. Cornea 2017:36:275-9.

111 Liarakos VS, Dapena I, Ham L, et al. Intraocular graft unfolding techniques in Descemet membrane endothelial keratoplasty. JAMA Ophthalmol 2013:131:29-35.

112 Yoeruek E, Bayyoud T, Hofmann J, et al. Novel maneuver facilitating Descemet membrane unfolding in the anterior chamber. Cornea 2013:32:370-3.

113 Heinzelmann S, Bohringer D, Haverkamp C, et al. Influence of postoperative intraocular pressure on graft detachment after Descemet membrane endothelial keratoplasty. Cornea 2018;37:1347-50.

114 Ang M, Mehta JS, Newman SD, et al. Descemet membrane endothelial keratoplasty: preliminary results of a donor insertion pull-through technique using a donor mat device. Am J Ophthalmol 2016;171:27-34.

115 Busin M, Leon P, D'Angelo S, et al. Clinical outcomes of preloaded Descemet membrane endothelial keratoplasty grafts with endothelium tri-folded inwards. Am J Ophthalmol 2018:193:106-13.

116 Leon $\mathrm{P}$, Parekh M, Nahum Y, et al. Factors associated with early graft detachment in primary Descemet membrane endothelial keratoplasty. Am J Ophthalmol 2018;187:117-24.

117 Price MO, Lisek M, Kelley M, et al. Endothelium-in versus endothelium-out insertion with Descemet membrane endothelial keratoplasty. Cornea 2018:37:1098-101.

118 Birbal RS, Hsien S, Zygoura V, et al. Outcomes of hemi-Descemet membrane endothelial keratoplasty for Fuchs endothelial corneal dystrophy. Cornea 2018:37:854-8.

119 Zygoura V, Baydoun L, Ham L, et al. Quarter-Descemet membrane endothelial keratoplasty (Quarter-DMEK) for Fuchs endothelial corneal dystrophy: 6 months clinical outcome. Br J Ophthalmol 2018;102:1425-30.

120 Agarwal A, Dua HS, Narang P, et al. Pre-Descemet's endothelial keratoplasty (PDEK). Br J Ophthalmol 2014;98:1181-5. 
121 Schlotzer-Schrehardt U, Bachmann BO, Tourtas T, et al. Ultrastructure of the posterior corneal stroma. Ophthalmology 2015;122:693-9.

122 Pascolini D, Mariotti SP. Global estimates of visual impairment: 2010. Br J Ophthalmol 2012:96:614-8.

123 Greenrod EB, Jones MN, Kaye $S$, et al. Center and surgeon effect on outcomes of endothelial keratoplasty versus penetrating keratoplasty in the United Kingdom. Am J Ophthalmol 2014;158:957-66.

124 Price FW Jr., Feng MT, Price MO. Evolution of endothelial keratoplasty: where are we headed? Cornea 2015;34:S41-7.

125 Shtein RM, Raoof-Daneshvar D, Lin HC, et al. Keratoplasty for corneal endothelial disease, 2001-2009. Ophthalmology 2012;119:1303-10.

126 Peh GS, Chng Z, Ang HP, et al. Propagation of human corneal endothelial cells: a novel dual media approach. Cell Transplant 2015;24:287-304.

127 Peh GS, Toh KP, Ang HP, et al. Optimization of human corneal endothelial cell culture: density dependency of successful cultures in vitro. BMC Res Notes 2013:6:176.

128 Peh GS, Toh KP, Wu FY, et al. Cultivation of human corneal endothelial cells isolated from paired donor corneas. PLoS One 2011;6:e28310.

129 Bostan C, Theriault M, Forget KJ, et al. In vivo functionality of a corneal endothelium transplanted by cell-injection therapy in a feline model. Invest Ophthalmol Vis Sci 2016;57:1620-34.

130 Mimura T, Yamagami S, Usui T, et al. Long-term outcome of iron-endocytosing cultured corneal endothelial cell transplantation with magnetic attraction. Exp Eye Res 2005;80:149-57.

131 Mimura T, Shimomura N, Usui T, et al. Magnetic attraction of ironendocytosed corneal endothelial cells to Descemet's membrane. Exp Eye Res 2003;76:745-51

132 Mimura T, Yokoo S, Araie M, et al. Treatment of rabbit bullous keratopathy with precursors derived from cultured human corneal endothelium. Invest Ophthalmol Vis Sci 2005:46:3637-44.

133 Mimura T, Yamagami S, Usui T, et al. Necessary prone position time for human corneal endothelial precursor transplantation in a rabbit endothelial deficiency model. Curr Eye Res 2007:32:617-23.

134 Peh GSL, Ong HS, Adnan K, et al. Functional evaluation of two corneal endothelial cell-based therapies: tissue-engineered construct and cell injection. Sci Rep 2019;9:6087.

135 Kinoshita S, Koizumi N, Ueno M, et al. Injection of cultured cells with a ROCK inhibitor for bullous keratopathy. N Engl J Med 2018;378:995-1003.

136 Ong HS, Peh G, Neo DJH, et al. A novel approach of harvesting viable single cells from donor corneal endothelium for cell-injection therapy. Cells 2020;9: E1428.

137 Patel SV, Bachman LA, Hann CR, et al. Human corneal endothelial cell transplantation in a human ex vivo model. Invest Ophthalmol Vis Sci 2009;50:2123-31.

138 Bartakova A, Kunzevitzky NJ, Goldberg JL. Regenerative cell therapy for corneal endothelium. Curr Ophthalmol Rep 2014;2:81-90.

139 Peh GSL, Ang HP, Lwin CN, et al. Regulatory compliant tissue-engineered human corneal endothelial grafts restore corneal function of rabbits with bullous keratopathy. Sci Rep 2017;7:14149.

140 Insler MS, Lopez JG. Transplantation of cultured human neonatal corneal endothelium. Curr Eye Res 1986;5:967-72.

141 Insler MS, Lopez JG. Extended incubation times improve corneal endothelial cell transplantation success. Invest Ophthalmol Vis Sci 1991;32:1828-36.

142 Insler MS, Lopez JG. Heterologous transplantation versus enhancement of human corneal endothelium. Cornea 1991;10:136-48.

143 Engelmann K, Friedl P. Optimization of culture conditions for human corneal endothelial cells. In Vitro Cell Develop Biol: I Tissue Culture Assoc 1989;25:1065-72.

144 Aboalchamat B, Engelmann K, Bohnke M, et al. Morphological and functional analysis of immortalized human corneal endothelial cells after transplantation. Exp Eye Res 1999;69:547-53.

145 Engelmann K, Drexler D, Bohnke M. Transplantation of adult human or porcine corneal endothelial cells onto human recipients in vitro. Part I: cell culturing and transplantation procedure. Cornea 1999;18:199-206.

146 Bohnke M, Eggli P, Engelmann K. Transplantation of cultured adult human or porcine corneal endothelial cells onto human recipients in vitro. Part II: evaluation in the scanning electron microscope. Cornea 1999;18:207-13.

147 Chen KH, Azar D, Joyce NC. Transplantation of adult human corneal endothelium ex vivo: a morphologic study. Cornea 2001;20:731-7.

148 Amano S. Transplantation of cultured human corneal endothelial cells. Cornea 2003;22:S66-74-

149 Mimura T, Amano S, Usui T, et al. Transplantation of corneas reconstructed with cultured adult human corneal endothelial cells in nude rats. Exp Eye Res 2004;79:231-7

150 Proulx S, Bensaoula T, Nada O, et al. Transplantation of a tissue-engineered corneal endothelium reconstructed on a devitalized carrier in the feline model. Invest Ophthalmol Vis Sci 2009;50:2686-94.
151 Ishino Y, Sano Y, Nakamura T, et al. Amniotic membrane as a carrier for cultivated human corneal endothelial cell transplantation. Invest Ophthalmol Vis Sci 2004;45:800-6.

152 Mimura T, Yamagami S, Yokoo S, et al. Cultured human corneal endothelial cell transplantation with a collagen sheet in a rabbit model. Invest Ophthalmol Vis Sci 2004:45:2992-7.

153 Honda N, Mimura T, Usui T, et al. Descemet stripping automated endothelial keratoplasty using cultured corneal endothelial cells in a rabbit model. Arch Ophthalmol 2009;127:1321-6.

154 Choi JS, Williams JK, Greven M, et al. Bioengineering endothelialized neo-corneas using donor-derived corneal endothelial cells and decellularized corneal stroma. Biomaterials 2010;31:6738-45.

155 Lai JY, Chen KH, Hsiue GH. Tissue-engineered human corneal endothelial cell sheet transplantation in a rabbit model using functional biomaterials. Transplant 2007:84:1222-32.

156 Watanabe R, Hayashi R, Kimura Y, et al. A novel gelatin hydrogel carrier sheet for corneal endothelial transplantation. Tissue Eng Part A 2011;17:2213-9.

157 Liang Y, Liu W, Han B, et al. Fabrication and characters of a corneal endothelial cells scaffold based on chitosan. J Mater Sci Mater Med 2011;22:175-83.

158 Peh GS, Beuerman RW, Colman A, et al. Human corneal endothelial cell expansion for corneal endothelium transplantation: an overview. Transplant 2011;91:811-9.

159 Adamis AP, Filatov V, Tripathi BJ, et al. Endothelial dystrophy of the cornea. Surv Ophthalmol 1993;38:149-68.

160 Rizwan M, Peh GS, Adnan K, et al. In vitro topographical model of Fuchs dystrophy for evaluation of corneal endothelial cell monolayer formation. Adv Healthc Mater 2016:5:2896-910

161 Kocaba V, Katikireddy KR, Gipson I, et al. Association of the gutta-induced microenvironment with corneal endothelial cell behavior and demise in Fuchs endothelial corneal dystrophy. JAMA Ophthalmol 2018;136:886-92.

162 Ang M, Konstantopoulos A, Goh G, et al. Evaluation of a micro-optical coherence tomography for the corneal endothelium in an animal model. Sci Rep 2016;6:29769.

163 Fernandes KJ, McKenzie IA, P M, et al. A dermal niche for multipotent adult skin-derived precursor cells. Nat Cell Biol 2004;6:1082-93.

164 Williams AL, Bohnsack BL. Neural crest derivatives in ocular development: discerning the eye of the storm. Birth Defects Res C Embryo Today 2015; 105:87-95

165 Zavala J, Lopez JGR, Rodriguez Barrientos CA, et al. Corneal endothelium: developmental strategies for regeneration. Eye (Lond) 2013;27:579-88.

166 Shen L, Sun P, Zhang C, et al. Therapy of corneal endothelial dysfunction with corneal endothelial cell-like cells derived from skin-derived precursors. Sci Rep 2017:7:13400.

167 Wagoner MD, Bohrer LR, Aldrich BT, et al. Feeder-free differentiation of cells exhibiting characteristics of corneal endothelium from human induced pluripotent stem cells. Biol Open 2018;7.

168 Gutermuth A, Maassen J, Harnisch E, et al. Descemet's membrane biomimetic microtopography differentiates human mesenchymal stem cells into corneal endothelial-like cells. Cornea 2019;38:110-19.

169 Mehta JS, Kocaba V, Soh YQ. The future of keratoplasty: cell-based therapy, regenerative medicine, bioengineering keratoplasty, gene therapy. Curr Opin Ophthalmol 2019:30:286-91.

170 Soh YQ, Peh Swee Lim G, Htoon HM, et al. Trinucleotide repeat expansion length as a predictor of the clinical progression of Fuchs' endothelial corneal dystrophy. PLOS One 2019;14:e0210996.

171 Pinto BS, Saxena T, Oliveira R, et al. Impeding transcription of expanded microsatellite repeats by deactivated cas9. Mol Cell 2017;68:479-90 e5.

172 Leung T, Manser E, Tan L, et al. A novel serine/threonine kinase binding the ras-related RhoA GTPase which translocates the kinase to peripheral membranes. J Biol Chem 1995;270:29051-4.

173 Matsui T, Amano M, Yamamoto T, et al. Rho-associated kinase, a novel serine/ threonine kinase, as a putative target for small GTP binding protein Rho. Embo J 1996;15:2208-16

174 Ishizaki T, Maekawa M, Fujisawa K, et al. The small GTP-binding protein binds to and activates a $160 \mathrm{kDa}$ Ser/Thr protein kinase homologous to myotonic dystrophy kinase. Embo J 1996;15:1885-93.

175 Liao JK, Seto M, Noma K. Rho kinase (ROCK) inhibitors. J Cardiovasc Pharmacol 2007:50:17-24.

176 Biro M, Munoz MA, Weninger W. Targeting Rho-GTPases in immune cell migration and inflammation. Br J Pharmacol 2014;171:5491-506.

177 Pakravan M, Beni AN, Ghahari E, et al. The ocular hypotensive efficacy of topical fasudil, a rho-associated protein kinase inhibitor, in patients with end-stage glaucoma. Am J Ther 2016.

178 Wang SK, Chang RT. An emerging treatment option for glaucoma: Rho kinase inhibitors. Clin Ophthalmol 2014;8:883-90.

179 Isobe T, Mizuno K, Kaneko Y, et al. Effects of K-115, a rho-kinase inhibitor, on aqueous humor dynamics in rabbits. Curr Eye Res 2014;39:813-22.

180 Kaneko Y, Ohta M, Inoue T, et al. Effects of K-115 (Ripasudil), a novel ROCK inhibitor, on trabecular meshwork and Schlemm's canal endothelial cells. Sci Rep 2016;6:19640 
181 Honjo $\mathrm{M}$, Tanihara $\mathrm{H}$, Inatani $\mathrm{M}$, et al. Effects of rho-associated protein kinase inhibitor Y-27632 on intraocular pressure and outflow facility. Invest Ophthalmol Vis Sci 2001;42:137-44

182 Kameda T, Inoue T, M I, et al. The effect of Rho-associated protein kinase inhibitor on monkey Schlemm's canal endothelial cells. Invest Ophthalmol Vis Sci 2012:53:3092-103

183 Tian B, Kaufman PL, Volberg T, et al. H-7 disrupts the actin cytoskeleton and increases outflow facility. Arch Ophthalmol 1998;116:633-43.

184 Rao PV, Deng PF, Kumar J, et al. Modulation of aqueous humor outflow facility by the Rho kinase-specific inhibitor Y-27632. Invest Ophthalmol Vis Sci 2001:42:1029-37

185 Rao PV, Deng P, Sasaki Y, et al. Regulation of myosin light chain phosphorylation in the trabecular meshwork: role in aqueous humour outflow facility. Exp Eye Res 2005;80:197-206

186 Feng Y, LoGrasso PV, Defert 0, et al. (ROCK) inhibitors and their therapeutic potential. J Med Chem 2016;59:2269-300.

187 Okumura N, Koizumi N, Kay EP, et al. The ROCK inhibitor eye drop accelerates corneal endothelium wound healing. Invest Ophthalmol Vis Sci 2013;54:2493-502.

188 Okumura N, Nakano S, Kay EP, et al. Involvement of cyclin D and p27 in cell proliferation mediated by ROCK inhibitors Y-27632 and Y-39983 during corneal endothelium wound healing. Invest Ophthalmol Vis Sci 2014;55:318-29.

189 Okumura N, Okazaki Y, Inoue R, et al. Effect of the rho-associated kinase inhibitor eye drop (Ripasudil) on corneal endothelial wound healing. Invest Ophthalmol Vis Sci 2016:57:1284-92.

190 Okumura N, Ueno M, Koizumi N, et al. Enhancement on primate corneal endothelial cell survival in vitro by a ROCK inhibitor. Invest Ophthalmol Vis Sci 2009:50:3680-7.

191 Koizumi N, Okumura N, Ueno M, et al. Rho-associated kinase inhibitor eye drop treatment as a possible medical treatment for Fuchs corneal dystrophy. Cornea 2013:32:1167-70.

192 Peh GS, Adnan K, George BL, et al. The effects of Rho-associated kinase inhibitor Y-27632 on primary human corneal endothelial cells propagated using a dual media approach. Sci Rep 2015;5:9167.

193 Kaufman AR, Nose RM, Pineda R 2nd. Descemetorhexis without endothelial keratoplasty (DWEK): proposal for nomenclature standardization. Cornea 2018;37:e20-e21.

194 Braunstein RE, Airiani S, Chang MA, et al. Corneal edema resolution after "descemetorhexis". J Cataract Refract Surg 2003;29:1436-9.

195 Borkar DS, Veldman P, Colby KA. Treatment of Fuchs endothelial dystrophy by Descemet stripping without endothelial keratoplasty. Cornea 2016;35:1267-73.

196 Soh YQ, Peh GS, Mehta JS. Evolving therapies for Fuchs' endothelial dystrophy. Regen Med 2018;13:97-115.

197 Artaechevarria Artieda J, Wells M, Devasahayam RN, et al. 5-year outcomes of Descemet stripping only in Fuchs dystrophy. Cornea 2020.

198 Garcerant D, Hirnschall N, Toalster N, et al. Descemet's stripping without endothelial keratoplasty. Curr Opin Ophthalmol 2019;30:275-85.

199 Macsai MS, Shiloach M. Use of topical rho kinase inhibitors in the treatment of Fuchs dystrophy after Descemet stripping only. Cornea 2019;38:529-34.

200 Bhogal M, Lwin CN, Seah XY, et al. Allogeneic Descemet's membrane transplantation enhances corneal endothelial monolayer formation and restores functional integrity following Descemet's stripping. Invest Ophthalmol Vis Sci 2017;58:4249-60.

201 Soh YQ, Mehta JS. Regenerative therapy for Fuchs endothelial corneal dystrophy. Cornea 2018:37:523-7.

202 Jullienne R, Manoli P, Tiffet T, et al. Corneal endothelium self-healing mathematical model after inadvertent descemetorhexis. J Cataract Refract Surg 2015:41:2313-8.

203 Soh YQ, Peh G, George BL, et al. Predicative factors for corneal endothelial cell migration. Invest Ophthalmol Vis Sci 2016;57:338-48.

204 Nguyen NX, Seitz B, Martus P, et al. Long-term topical steroid treatment improves graft survival following normal-risk penetrating keratoplasty. Am J Ophthalmol 2007;144:318-9.

205 Anshu A, Price MO, Price FW Jr. Risk of corneal transplant rejection significantly reduced with Descemet's membrane endothelial keratoplasty. Ophthalmology 2012:119:536-40

206 Cornea Donor Study Investigator Group. Donor age and corneal endothelial cell loss 5 years after successful corneal transplantation. Specular microscopy ancillary study results. Ophthalmology 2008;115:627-32 e8.

207 Dandona L, Naduvilath TJ, Janarthanan M, et al. Survival analysis and visual outcome in a large series of corneal transplants in India. Br J Ophthalmol 1997;81:726-31.
208 Dickman MM, Peeters JM, van den Biggelaar FJ, et al. Changing practice patterns and long-term outcomes of endothelial versus penetrating keratoplasty: a prospective Dutch registry study. Am J Ophthalmol 2016;170:133-42.

209 Stewart RM, Jones MN, Batterbury M, et al. Effect of glaucoma on corneal graft survival according to indication for penetrating keratoplasty. Am J Ophthalmol 2011:151:257-62 e1.

210 Sugar A, JP T, Dontchev M, et al. Recipient risk factors for graft failure in the cornea donor study. Ophthalmology 2009;116:1023-8.

211 Williams KA, Lowe M, Bartlett C, et al. Risk factors for human corneal graft failure within the Australian Corneal Graft Registry. Transplant 2008;86:1720-4.

212 Lee WB, Jacobs DS, Musch DC, et al. Descemet's stripping endothelial keratoplasty: safety and outcomes: a report by the American Academy of Ophthalmology. Ophthalmol 2009:116:1818-30.

213 Terry MA, Wall JM, Hoar KL, et al. A prospective study of endothelial cell loss during the 2 years after deep lamellar endothelial keratoplasty. Ophthalmology 2007; 114:631-9.

214 Li JY, Terry MA, Goshe J, et al. Graft rejection after Descemet's stripping automated endothelial keratoplasty: graft survival and endothelial cell loss. Ophthalmology 2012;119:90-4.

215 Jordan CS, Price MO, Trespalacios R, et al. Graft rejection episodes after Desceme stripping with endothelial keratoplasty: part one: clinical signs and symptoms. $\mathrm{Br}$ J Ophthalmol 2009:93:387-90.

216 Suh LH, Yoo SH, Deobhakta A, et al. Complications of Descemet's stripping with automated endothelial keratoplasty: survey of 118 eyes at one institute. Ophthalmology 2008;115:1517-24.

217 Khor WB, Han SB, Mehta JS, et al. Descemet stripping automated endothelial keratoplasty with a donor insertion device: clinical results and complications in 100 eyes. Am J Ophthalmol 2013;156:773-9.

218 Price DA, Kelley M, Price FW Jr., et al. Five-year graft survival of Descemet membrane endothelial keratoplasty (EK) versus Descemet stripping EK and the effect of donor sex matching. Ophthalmology 2018;125:1508-14.

219 Wacker K, Baratz KH, Maguire LJ, et al. Descemet stripping endothelial keratoplasty for Fuchs' endothelial corneal dystrophy: five-year results of a prospective study. Ophthalmology 2016;123:154-60

220 Fajgenbaum MA, Hollick EJ. Modeling endothelial cell loss after Descemet stripping endothelial keratoplasty: data from 5 years of follow-up. Cornea 2017:36:553-60.

221 Vajaranant TS, Price MO, Price FW, et al. Visual acuity and intraocular pressure afte Descemet's stripping endothelial keratoplasty in eyes with and without preexisting glaucoma. Ophthalmology 2009;116:1644-50.

222 Lee JS, Desai NR, Schmidt GW, et al. Secondary angle closure caused by air migrating behind the pupil in Descemet stripping endothelial keratoplasty. Cornea 2009;28:652-6

223 Espana EM, Robertson ZM, Huang B. Intraocular pressure changes following Descemet's stripping with endothelial keratoplasty. Graefes Arch Clin Exp Ophthalmol 2010;248:237-42.

224 Deng SX, Lee WB, Hammersmith KM, et al. Descemet membrane endothelial keratoplasty: safety and outcomes: a report by the American Academy of Ophthalmology. Ophthalmology 2018;125:295-310.

225 Melles GR, Ong TS, Ververs B, et al. Preliminary clinical results of Descemet membrane endothelial keratoplasty. Am J Ophthalmol 2008;145:222-7.

226 Ham L, Dapena I, Liarakos VS, et al. Midterm results of Descemet membrane endothelial keratoplasty: 4 to 7 years clinical outcome. Am J Ophthalmol 2016;171:113-21

227 Guerra FP, Anshu A, Price MO et al. Descemet's membrane endothelial keratoplasty: prospective study of 1-year visual outcomes, graft survival, and endothelial cell loss. Ophthalmology 2011:118:2368-73.

228 Gorovoy IR, Gorovoy MS. Descemet membrane endothelial keratoplasty postoperative year 1 endothelial cell counts. Am J Ophthalmol 2015;159:597-600 e2.

229 Schlogl A, Tourtas T, Kruse FE, et al. Long-term clinical outcome after Descemet membrane endothelial keratoplasty. Am J Ophthalmol 2016;169:218-26.

230 Naveiras M, Dirisamer M, Parker J, et al. Causes of glaucoma after Descemet membrane endothelial keratoplasty. Am J Ophthalmol 2012;153:958-66 e1.

231 Price MO, Price FW Jr., Kruse FE, et al. Randomized comparison of topical prednisolone acetate $1 \%$ versus fluorometholone $0.1 \%$ in the first year after Descemet membrane endothelial keratoplasty. Cornea 2014;33:880-6. 


\title{
Correction: Evolution of therapies for the corneal endothelium: past, present and future approaches
}

Ong HS, Ang M, Mehta J. Evolution of therapies for the corneal endothelium: past, present and future approaches. Br J Ophthalmol 2021;105:454-67. doi:10.1136/ bjophthalmol-2020-316149

The third authors initials should be Mehta JS rather than Mehta J.

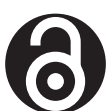

\section{OPEN ACCESS}

\begin{abstract}
Open access This is an open access article distributed in accordance with the Creative Commons Attribution Non Commercial (CC BY-NC 4.0) license, which permits others to distribute, remix, adapt, build upon this work noncommercially, and license their derivative works on different terms, provided the original work is properly cited, appropriate credit is given, any changes made indicated, and the use is non-commercial. See: http://creativecommons.org/licenses/by-nc/ 4.0\%.

(C) Author(s) (or their employer(s)) 2023. Re-use permitted under CC BY-NC. No commercial re-use. See rights and permissions. Published by BMJ.
\end{abstract}

Br J Ophthalmol 2023;107:e1. doi:10.1136/bjophthalmol-2020-316149.corr1

(A) Check for updates 